\title{
Differential Effects of Toll-Like Receptor Activation and Differential Mediation by MAP Kinases of Immune Responses in Microglial Cells
}

\author{
Jaedeok Kwon ${ }^{1,2} \cdot$ Christos Arsenis $^{1} \cdot$ Maria Suessmilch $^{2} \cdot$ Alison McColl $^{2} \cdot$ Jonathan Cavanagh $^{2} \cdot$ Brian J. Morris $^{1}$ (D)
}

Received: 22 March 2021 / Accepted: 10 July 2021 / Published online: 23 July 2021

(c) The Author(s) 2021

\begin{abstract}
Microglial activation is believed to play a role in many psychiatric and neurodegenerative diseases. Based largely on evidence from other cell types, it is widely thought that MAP kinase (ERK, JNK and p38) signalling pathways contribute strongly to microglial activation following immune stimuli acting on toll-like receptor (TLR) 3 or TLR4. We report here that exposure of SimA9 mouse microglial cell line to immune mimetics stimulating TLR4 (lipopolysaccharide-LPS) or TLR7/8 (resiquimod/R848), results in marked MAP kinase activation, followed by induction of nitric oxide synthase, and various cytokines/chemokines. However, in contrast to TLR4 or TLR7/8 stimulation, very few effects of TLR3 stimulation by polyinosine/cytidine (polyI:C) were detected. Induction of chemokines/cytokines at the mRNA level by LPS and resiquimod were, in general, only marginally affected by MAP kinase inhibition, and expression of $T N F, C c l 2$ and $C c l 5$ mRNAs, along with nitrite production, were enhanced by p38 inhibition in a stimulus-specific manner. Selective JNK inhibition enhanced Ccl2 and Ccl5 release. Many distinct responses to stimulation of TLR4 and TLR7 were observed, with JNK mediating TNF protein induction by the latter but not the former, and suppressing Ccl5 release by the former but not the latter. These data reveal complex modulation by MAP kinases of microglial responses to immune challenge, including a dampening of some responses. They demonstrate that abnormal levels of JNK or p38 signalling in microglial cells will perturb their profile of cytokine and chemokine release, potentially contributing to abnormal inflammatory patterns in CNS disease states.
\end{abstract}

Keywords Microglia $\cdot$ Viral infection $\cdot$ Bacterial infection $\cdot$ Cytokines $\cdot$ Chemokines $\cdot$ Signaling Pathway $\cdot$ Poly (IC)

Jonathan Cavanagh and Brian J. Morris have contributed equally, joint senior authors.

Brian J. Morris

Brian.Morris@glasgow.ac.uk

Jaedeok Kwon

j.kwon.1@ research.gla.ac.uk

Maria Suessmilch

m.suessmilch.1@research.gla.ac.uk

Alison McColl

Alison.Mccoll@glasgow.ac.uk

Jonathan Cavanagh

Jonathan.Cavanagh@glasgow.ac.uk

1 Institute of Neuroscience and Psychology, College of Medical, Veterinary and Life Sciences, University of Glasgow, West Medical Building, Glasgow G12 8QQ, UK

2 Institute of Infection, Immunity and Inflammation, University of Glasgow, Glasgow, UK

\section{Introduction}

Inappropriate microglial activation is a component of most neurodegenerative diseases. In Alzheimer's disease, for example, activated microglia surround amyloid plaques, and genetic evidence implies strongly that microglia directly influence the neurodegenerative process (Yeh et al. 2017; Efthymiou and Goate 2017; Baufeld et al. 2018). In certain psychiatric diseases, most prominently schizophrenia, there is also evidence that microglia contribute to disease aetiology (Takahashi et al. 2016; Herron et al. 2018). The epidemiological evidence that exposure to viral infection in utero increases schizophrenia risk in offspring is consistent with inappropriate microglial activation during development as a component of disease causation.

In Alzheimer's disease (AD), there are many reports of abnormal levels of chemokines/cytokines in plasma, cerebrospinal fluid and post-mortem tissue (Swardfager et al. 2010), although many are contradictory. Conversely, equivalent studies in schizophrenia consistently indicate elevated 
CNS cytokine and chemokine expression (Zhang et al. 2002; Miller et al. 2011; Hong et al. 2017). For example, robust increases in interleukin 6 (IL-6) are detected in cerebrospinal fluid in patients samples, whilst in post-mortem tissue, increased inflammatory markers such as $C X C L 8, I L-1 \beta$, and IL-6 mRNAs are detected in dorsolateral prefrontal cortex from patients (Fillman et al. 2013).

The possibility of microglial involvement in a range of CNS diseases becomes of significant interest considering that complementary evidence links signalling via the JNK subgroup of MAP kinase cascades to the aetiology of the same diseases. JNK phosphorylation (activation) is elevated in neurons showing early signs of A $\beta 1-42$ accumulation in $\mathrm{AD}$ and is also increased in prefrontal cortex and hippocampus in later stage AD (Del Villar and Miller 2004; Swatton et al. 2004; Mufson et al. 2012), and JNKs are considered as potential therapeutic targets (Yarza et al. 2016). JNK activation is also heavily implicated in the neurotoxic responses to CNS-penetrant viruses, such as polio virus, west nile virus, Human immunodeficiency virus (HIV) and Herpes simple virus (HSV) (Michaelis et al. 2007; Autret et al. 2008; Crews et al. 2009; Cliffe et al. 2015; Beckham et al. 2007). Genetic evidence supports the involvement of JNK signalling in schizophrenia aetiology (Winchester et al. 2012; Morris and Pratt 2014).

Toll-like receptors (TLRs), which detect the presence of tissue pathogens such as bacteria and viruses, are expressed by immune cells including monocytes and macrophages, and also in CNS microglia. Many signalling pathways interact to regulate microglial activation in response to immune challenge. Most prominent amongst these are the nuclear factor kappa-light-chain-enhancer of activated B cells (NF- $\mathrm{kB})$ and MAP kinase (ERK, p38 and JNK) cascades, which combine to induce proliferation, morphological change, migration, and synthesis and release of inflammatory mediators including nitric oxide, cytokines and chemokines (Dong et al. 2002). The JNK pathway is known to contribute to the activation of $\mathrm{T}$ cells and macrophages, but the extent to which JNK signalling is involved in microglial activation is less clear. For example, induction of TNF, IL-2, and CCL5 following immune challenge is reduced in mice lacking JNK1 (Tran et al. 2006). Conversely, induction of inducible nitric oxide synthase (NOS2, iNOS) and IL-6 is enhanced in bone-marrow-derived macrophages (BMDMs) from mice lacking JNK1 (Zhao et al. 2017).

Most studies compare the effects of TLR4, responding to bacterial mimetics such as lipopolysaccharide (LPS) and TLR3, responding to double-stranded virus mimetics such as poly inosine-cytosine (poly I:C). There is limited information concerning responses to mimetics of singlestranded viruses, such as resiquimod/R848 (Hemmi et al. 2002), which act on TLR7 and TLR8. In view of epidemiological evidence linking single-stranded virus exposure to psychiatric and neurological diseases, this is an important area that needs to be addressed.

In pursuit of an improved understanding of the mechanisms involved in microglial activation, we were also keen to assess the extent to which MAP kinase signalling, and in particular the JNK pathway, mediates microglial responses to immune challenge. There is a concern that viral immortalisation causes established microglial cell lines to be unrepresentative of their in vivo counterparts (Henn et al. 2009; Stansley et al. 2012; Butovsky et al. 2014; Das et al. 2016). Most of these lines stem from primary microglia cultures derived from the brain or the spinal cord, which were immortalized by viral transduction with oncogenes, e.g. BV2 (Blasi et al. 1990) or N9 (Righi et al. 1989) cell lines. This is a particular issue for studying MAP kinase involvement in cell responses, since in many cases the immortalisation involves increasing MAP kinase activity. Whilst advantages of cell lines include their ease of maintenance and their abundant availability due to their unrestricted proliferative capacity, a major disadvantage is that viral transformation or immortalization may alter the microglial phenotype. Recent studies have pointed out that microglia cell lines differ both genetically and functionally from primary microglia and ex vivo microglia (Butovsky et al. 2014; Das et al. 2016; Melief et al. 2016). The SIM-A9 cell line derived from a population of spontaneously transformed microglia in a primary mouse cortical culture (Nagamoto-Combs et al. 2014), and hence may be more closely related to microglia in vivo. In this study, we use SIM-A9 mouse microglial cells to probe the similarities and differences between activation of TLR3, TLR4 and TLR7/8, and the contribution of MAP kinase pathways to microglial responses.

\section{Materials and Methods}

\section{Cell Culture and Stimulation}

Murine microglial cells (SIM-A9) (RRID:CVCL_5I31) (Nagamoto-Combs et al. 2014) were purchased from ATCC (CRL3265). To expand the population, the cells were grown in DMEM:F12 (Gibco 302006) containing 5\% horse serum (Gibco-26050-088) with 1\% penicillin/streptomycin. The cells were detached with Trypsin/EDTA. For the immune stimulation describe below, required drugs were added after horse serum was removed (i.e., serum-free conditions).

LPS (Sigma, L-8274, $50 \mathrm{ng} / \mathrm{ml}(100 \mathrm{ng} / \mathrm{ml}$ for Griess assay), $\mathrm{dH}_{2} \mathrm{O}$ ), Poly I:C (LMW, Invivogen, Tlrl-picw, $100 \mathrm{ng} / \mathrm{ml}, \mathrm{dH}_{2} \mathrm{O}$ ), and resiquimod (Tocris, resiquimod, $3 \mu \mathrm{M}, \mathrm{DMSO}$ ) were used to induce immune responses. JNKIN-8 (Sigma, SML1246, 1 M, DMSO), PD98059 (Calbiochem, 513000, $40 \mu \mathrm{M}$, DMSO), SB203580 (Calbiochem, $559389,5 \mu \mathrm{M}$, DMSO) were used to inhibit specific MAP 
kinases, and they were added $3 \mathrm{~h}$ (JNK-IN-8)(Zhang et al. 2012) or 30 min (PD98059, SB203580) prior to immune stimuli.

\section{RNA Extraction and RT-qPCR}

Total RNA was extracted from the cell culture after various experimental conditions using an RNeasy mini kit (Qiagen, 79254) with additional DNase I (Qiagen, 79254) as per manufacture's instruction. The RNA concentration was determined by a Nanodrop DeNovix DS-11+ Spectrophotometer. RNA was reverse-transcribed to cDNA using High-capacity RNA-to-cDNA ${ }^{\mathrm{TM}}$ kit (Applied Biosystems, 4387406) according to the manufacturer's instruction.

Gene expression in the cells was quantified Fast SybrGreen $^{\mathrm{TM}}$ master mix (Applied Biosystems, 4385612) for each target using the QuantaStudio7 (Thermo Fisher Scientist). Primer sequences are provided in Supplementary Table 1. The level of the target genes was normalised to a geometric mean of two reference genes (Gapdh, Henmt1), which were not significantly different within treatment groups, and relative differences in target gene expression were determined using absolute quantification method.

Only for $T l r$ expression analysis, the relative quantification method $\left(2^{-\Delta \Delta \mathrm{CT}}\right)$ was used. The arbitrary value relative to Gapdh was compared to the average of all control (no RT) values as an index of relative expression.

\section{Griess Assay}

Cell culture media were collected and transferred to a 96 well plate. The culture media were mixed with an equal volume of the Griess assay reagent (Enzo Life Sciences, ALX-400-004-L050) and incubated for 10-15 min under dark condition. Measurements were taken (Multiskan ${ }^{\circledR}$ Spectrum; Thermo Scientific ${ }^{\mathrm{TM}}, 540 \mathrm{~nm}$ ), operated via the SkanIt ${ }^{\mathrm{TM}}$ software (Thermo Scientific ${ }^{\mathrm{TM}}$ ). $650 \mathrm{~nm}$ absorbance was taken for the reference.

\section{Western Blot}

Western blotting was performed essentially as described previously (Guilding et al. 2007). The cells were stimulated with pathogen mimetics for $15 \mathrm{~min}$ and proteins were extracted from the stimulated cells using ice-cold RIPA buffer $(10 \mathrm{mM}$ Tris- $\mathrm{HCl}(\mathrm{pH} 7.4)+150 \mathrm{mM} \mathrm{NaCl}+1 \mathrm{mM}$ EDTA $+1 \%(\mathrm{v} / \mathrm{v})$ Triton $\mathrm{x}-100+0.1 \%(\mathrm{w} / \mathrm{v})$ SDS $+0.5 \%(\mathrm{w} / \mathrm{v})$ sodium deoxycholate $+\mathrm{dH}_{2} \mathrm{O}+1 \%(\mathrm{v} / \mathrm{v})$ proteinase inhibitors (Sigma, P8340) + $1 \mathrm{mM}$ Sodium Orthovanadate + $2.5 \mathrm{mM}$ Sodium Pyrophosphate $+25 \mathrm{mM}$ Sodium Fluoride) and the lysate was centrifuged at $8000 \times g$ for $10 \mathrm{~min}$ at $4{ }^{\circ} \mathrm{C}$. The supernatant was kept at $-20^{\circ} \mathrm{C}$ till further use. Proteins were mixed with sample buffer (NuPAGE®, Invitrogen, NP0007) and the reducing agent (NuPAGE®, Invitrogen, 1769410) and heated for $10 \mathrm{~min}$ at $80{ }^{\circ} \mathrm{C}$. Preheated samples and protein ladder (Bio-Rad, 161-0375) were loaded onto a pre-cast gel (10\% Bis-Tris gel, NuPAGE®, Invitrogen) and transferred to pre-methanol/diluted NuPAGE transfer buffer soaked PVDF membrane $(0.45 \mu \mathrm{m}$ pore size, Novex, LC2005) NUPAGE transfer PVDF membranes. The transferred membranes were blocked by $5 \%$ milk/TBS-T for $30 \mathrm{~min}$ at room temperature and incubated with primary antibody overnight at $4{ }^{\circ} \mathrm{C}$ with gentle shaking (pJNK, Abcam, ab76572, 1:10000; pERK, Cell Signaling Technology (CST), 4377, 1:5000; pp38, CST, 4511, 1:4000; GAPDH Genetex, GTX627408, 1:20000). Specificity of the antibodies was assessed by the presence of a single band of the predicted size (in Kda) in our western blots (Supplementary Figure 5), and by inspection of literature data of immunoreactivity absence in mice with the corresponding gene deleted. The membranes were washed three times for 10 min each in TBS-T and incubated with secondary antibody (anti-Rabbit, Merck 12-348, 1:10000 in $1 \%$ milk/TBS-T) for $2 \mathrm{~h}$ at room temperature. Washes were repeated after secondary antibody incubation, washing three times for $10 \mathrm{~min}$, first washing in TBS-T and then last two washing in $10 \times$ TBS. Blots were developed via ECL (Millipore, WBKLS0100; or CST, 6883S), and images captured (Syngene PXi).

\section{Gel Electrophoresis}

cDNA samples were mixed with $5 \mu$ of SybrGreen (Applied Biosystems, Fast SYBR ${ }^{\mathrm{TM}}$ green master mix, 4385612), $0.3 \mu \mathrm{l}$ of a target gene of forward primer, $0.3 \mu \mathrm{l}$ of a target gene of reverse primer, and $3.4 \mu \mathrm{l}$ of RNase free water. The PCR was $95{ }^{\circ} \mathrm{C}$ for 3 min followed by 40 cycles of $95{ }^{\circ} \mathrm{C}$ for $3 \mathrm{~s}, 60^{\circ} \mathrm{C}$ for $30 \mathrm{~s}$, and $95{ }^{\circ} \mathrm{C}$ for $1 \mathrm{~min}$. The final PCR products were run on a $1.5 \%$ agarose gel $(120 \mathrm{~V}, 45 \mathrm{~min})$. The gel was imaged under UV lamp machine (Alpha Innotech, AlphaImage ${ }^{\mathrm{TM}}$ ).

\section{ELISA}

Secreted cytokines and chemokines from the stimulated cells were measured by ELISA kits (IL-6, eBiosciece ${ }^{\mathrm{TM}}$, 12364003; TNF-a, eBiosciece ${ }^{\mathrm{TM}}$, 155501117; CCL2, eBiosciece $^{\mathrm{TM}}$, 15561137; CCL5, R\&D system, DY478-05, CXCL10, R\&D system, DY466-05) per manufacturers' instructions. The culture media were stored at $-80{ }^{\circ} \mathrm{C}$ if they were not immediately used.

\section{Statistics}

A priori sample size calculations were performed, based on our previous experience with these techniques, assuming a minimum power of 0.8 and significance level of $p<0.05$ 
for ANOVA main effects (Minitab). All results are reported as groups means \pm SEM. No outliers were removed. Any deviation from normality of distribution (Kolmogorov - Smirnov test) and homogeneity of variance was assessed using Minitab. Non-normally distributed data were log transformed, and two-way or three-way analysis of variance (ANOVA) with post hoc Tukey multiple tests conducted (Minitab). For small sub-group sizes, individual planned comparisons between groups were also performed using a Fisher-Pitman permutation test. Details of the results of the statistical analysis are given in figure legends and in Supplementary Table 2.

\section{Results}

\section{Resting Microglial Cells Show Low Expression of TLR3 and TLR8}

Previous studies (Bsibsi et al. 2002; Olson and Miller 2004; Trudler et al. 2010) have compared the expression of TLRs in microglial cells maintained in serum, and hence likely to be under some degree of stimulation. To assess the relative expression of TLR3, TLR4, TLR7 and TLR8 in resting microglial cells, grown in serum-free conditions, prior to using agents stimulating these receptors to study the microglial responses, we used PCR to amplify the corresponding mRNAs (Fig. 1). At the mRNA level, Tlr3 and Tlr8 mRNAs showed a relatively low expression level compared to Tlr4 and $T l r 7$ mRNAs.

\section{TLR Stimulation Activates MAPK Pathways}

We assessed the extent to which immune mimetics were able to activate MAP kinase signalling in the microglial cells. The cells were stimulated with one of three different pathogen mimetics: resiquimod (TLR7/8 agonist) activated pMAPKs 15 min after stimulation (JNK, ERK and p38)
(Fig. 2), however LPS and poly I:C did not show any meaningful changes. With a slightly longer exposure time, after 30 min, LPS appeared to produce activation of pMAPKs, poly I:C rarely showed significant changes compared to LPS and resiquimod, even though pp38 appeared to be decreased at $30 \mathrm{~min}$ point (Supplementary Figures 1 and 2). The lack of MAPK phosphorylation after poly I:C stimulation may be a result of the low expression of Tlr3. These results indicate that microglial TLR4 and TLR7 use MAPKs as part of their response to immune stimuli. MAPKs have different isoforms. These isoforms have distinct expression patterns and their different biological function have been reported (Pagès et al. 1999; Kuan et al. 1999; Coffey 2014). For example, $J n k 1$ and $J n k 2$ are expressed through the body, although $J n k 3$ is expressed in limited organs such as the brain, and heart (Davis 2000). Therefore, it is important to know how individual isoform expression varies. Our results showed that JNK isoforms were significantly changed (Fig. 2A,B), and also both ERK isoforms (Fig. 2C,D).

\section{Nitric Oxide Production After Immune Challenge}

We then assessed the extent to which immune mimetics were able to stimulate an immune response in the microglial cells To monitor microglial activation after the stimuli, nitrite production was measured as an index of inducible nitric oxide synthase (iNOS) induction. Nitrite production was significantly increased by LPS and resiquimod but not by poly I:C (Fig. 3A). In order to understand MAPK effects on iNOS production, three different inhibitors were given before LPS and resiquimod. JNK and ERK inhibition reduced nitrite production under the LPS condition, but not with resiquimod (Fig. 3B-2, B-3). p38 inhibition tended to increase nitrite production with resiquimod $(\mathrm{F}(3,42)=8.175, p=0.0002$; resiquimod vs. resiquimod $+\mathrm{SB} 203580, p=0.0439$; Bonferroni post hoc) (Fig. 3B-3). This observation suggests differences in MAPK involvement downstream of TLR4 and

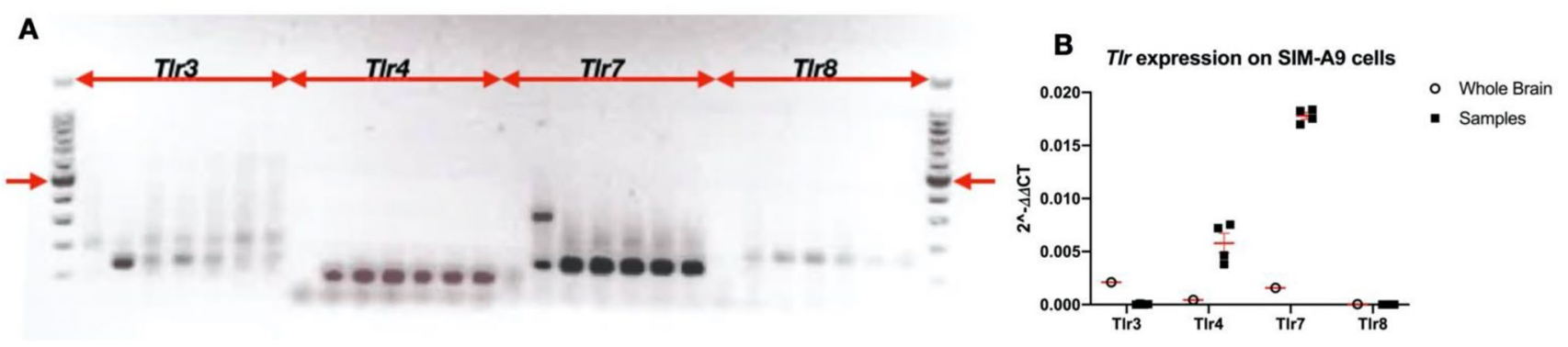

Fig. $1 T l r$ expression in SIM-A9 microglial cells. The cells were maintained under serum-free conditions overnight prior to RNA extraction and PCR. A A 100 bp DNA ladder is shown at left and right (red arrow indicates $500 \mathrm{bp}$ ). Loading order, negative control, positive control (cDNA from whole mouse brain), and five independent SimA9 cell samples; loading order was repeated for each TLR. B Relative quantification of Tlr expression on SIM-A9 cell samples, whole brain cDNA was used as a positive control ( $n=5-6 /$ group) 

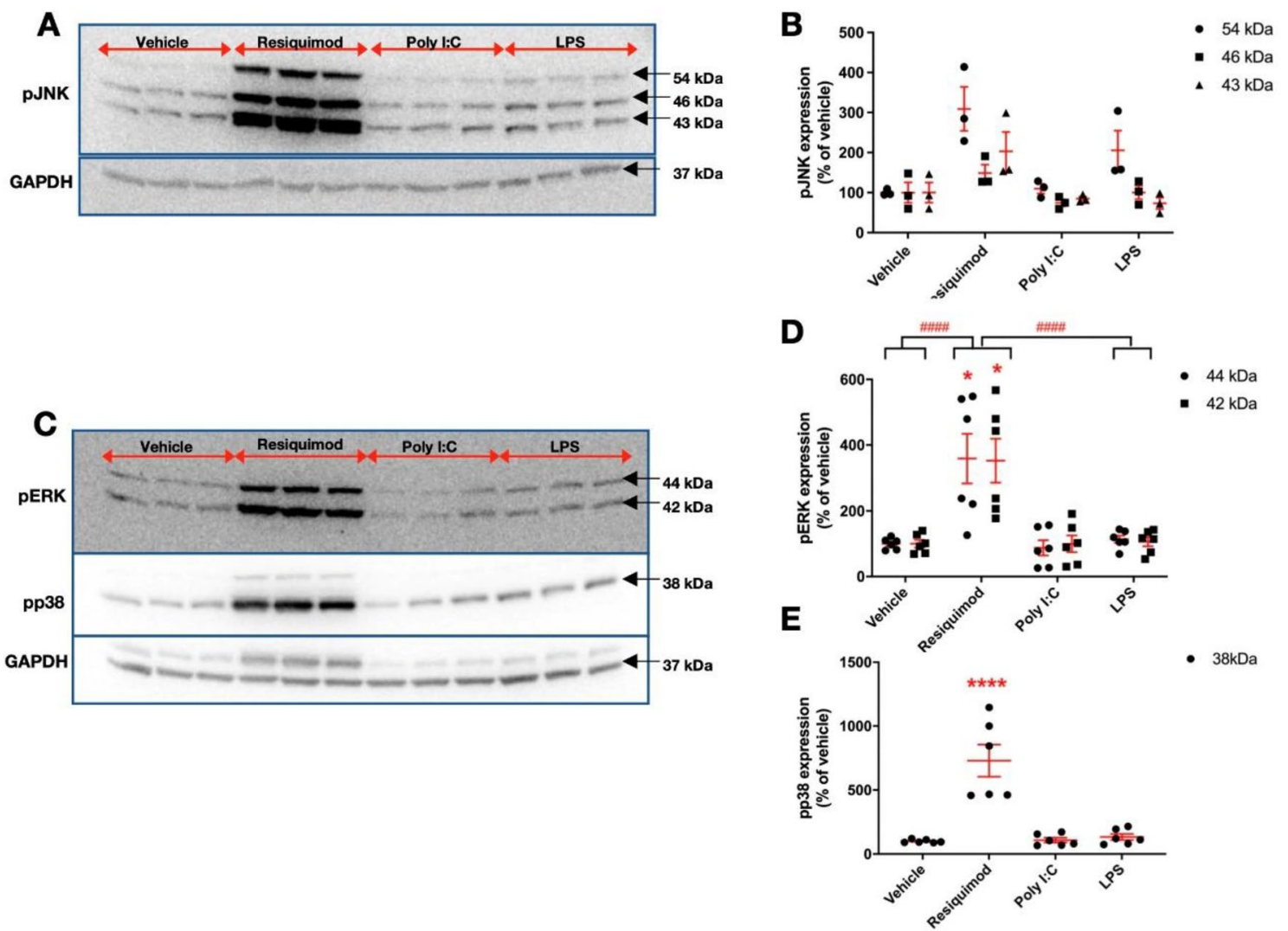

Fig. 2 Resiquimod induces MAPK phosphorylation in microglial cells. The microglial cells were cultured in serum-free medium overnight, and treated with LPS (50 ng/ml), poly I:C (100 ng/ $\mathrm{ml})$, or resiquimod $(3 \mu \mathrm{M})$ for $15 \mathrm{~min}$. A Resiquimod increases the level of pJNK compared to poly I:C or LPS. B The pJNK levels appear increased with resiquimod compared to vehicle. $\mathbf{C}$ and D Resiquimod, but not poly I:C or LPS, increases pERK and pp38 levels significantly. $\mathbf{C}$ and $\mathbf{E}$ Resiquimod increased pp38 levels significantly. One representative blot out of two independent experi-

TLR7/8, with greater involvement of ERK and JNK in TLR4 signalling.

\section{Time Course of Cytokine and Chemokine Responses}

To explore other consequences of the immune challenge, the cells were stimulated for three different time points, $0.5,8$, $24 \mathrm{~h}$ in serum-free conditions, and cytokine and chemokine responses were measured, at both mRNA and protein level. Il-6 mRNA significantly increased after LPS and resiquimod stimulation, however no changes were detected with poly I:C (Fig. 4A). Il-6 mRNA levels continuously increased to $24 \mathrm{~h}$. Tnf mRNA showed the peak stimulation at $0.5 \mathrm{~h}$, after which its level gradually decreased (Fig. 4C). Again, poly I:C did not make any meaningful changes. Interestingly, IL-6 protein only showed detectable changes after $8 \mathrm{~h}$; $0.5 \mathrm{~h}$ levels were below the quantification limit (data not shown), even though mRNA levels were raised from $0.5 \mathrm{~h}$ ment images is shown for A and C. Individual dots are shown along with mean \pm SEM. The data were analysed by two-way ANOVA, Tukey comparison (pJNK, pERK) and by one-way ANOVA, Bonferroni comparison (pp38) $(* p<0.05, * * * * p \leq 0.0001$ vs. same isoform in vehicle group; \#\#\#\# $p \leq 0.0001$ overall effect Tukey comparisons). ( $n=3-6 /$ group). Details of ANOVA $F$ values and $p$ values and of Fisher-Pitman permutation testing are provided in Supplementary Table 2

(Fig. 4B). TNF protein was significantly increased at 8 and $24 \mathrm{~h}$ (Fig. 4D). Thus whilst both $T N F$ and $\mathrm{Il}-6$ genes are induced rapidly after TLR stimulation, $I l-6$ mRNA levels continue to increase over $24 \mathrm{~h}$, whereas Tnf mRNA levels start to decline. However, the levels of both proteins released from the cells rises over the $24 \mathrm{~h}$ period. At the concentrations used, resiquimod produced a greater release of TNF protein, compared to LPS (Fig. 4).

In contrast to pro-inflammatory cytokines, the time courses of changes in chemokine expression were almost consistent. $\mathrm{Ccl} 2, \mathrm{Ccl} 5$ and $\mathrm{Cxcl} 10 \mathrm{mRNA}$ levels robustly increased from $8 \mathrm{~h}$ and their levels remained at roughly the same level until $24 \mathrm{~h}$ (Fig. 5A,C,E). Thus the induction of these chemokine mRNAs showed a different temporal profile from both $T N F$ and $I l-6$, with no further increase after $8 \mathrm{~h}$. Responses to LPS and resiquimod were generally similar, but interestingly, Cxcl10 mRNA showed measurable changes at $0.5 \mathrm{~h}$ with resiquimod but not LPS (Fig. 5E). Despite the LPS effect on 

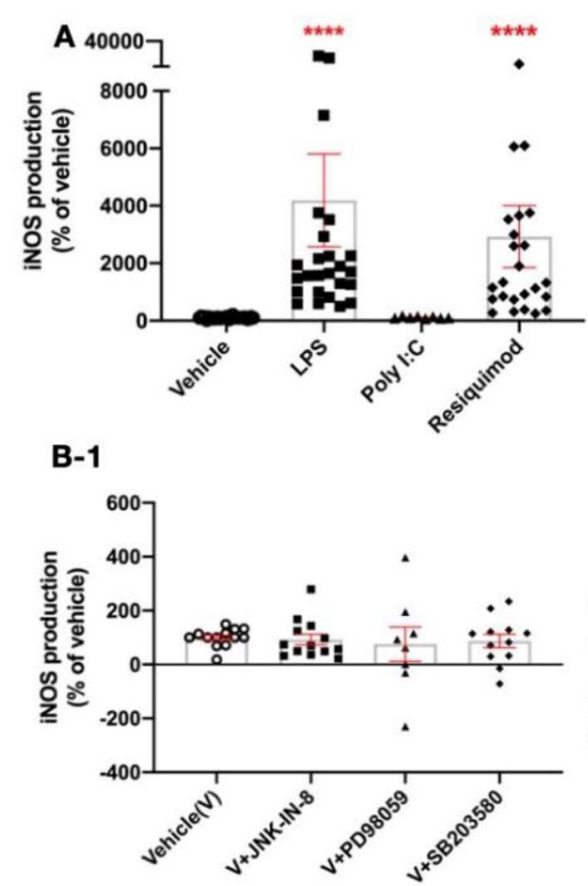

B-2

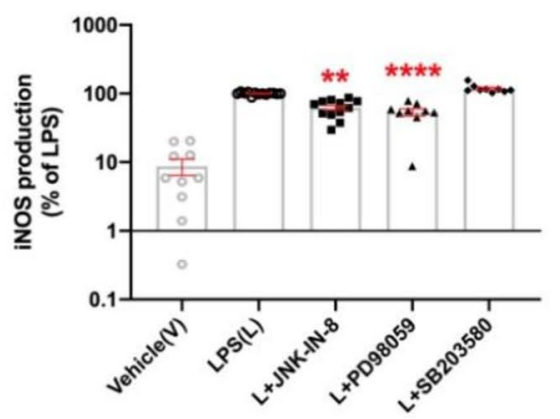

B-3

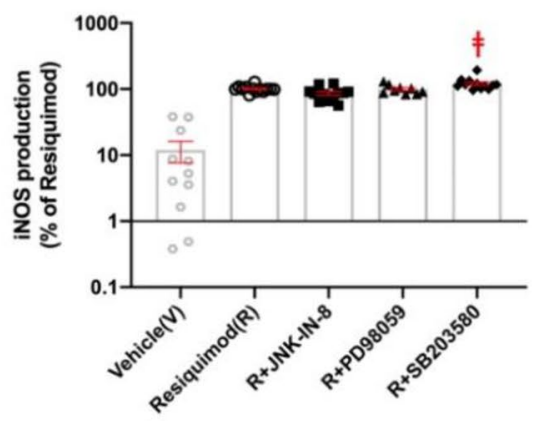

Fig. 3 iNOS production. The microglial cells were cultured in serumfree medium and left overnight before use. The cells were stimulated by LPS $(100 \mathrm{ng} / \mathrm{ml})$, poly I:C $(100 \mathrm{ng} / \mathrm{ml})$ or resiquimod $(3 \mu \mathrm{M})$ for $24 \mathrm{~h}$ and MAPK inhibitors, JNK-IN-8 $(1 \mu \mathrm{M})$, PD98059 $(40 \mu \mathrm{M})$, or SB203580 $(5 \mu \mathrm{M})$, were added before the mimetics. A iNOS was increased by LPS and resiquimod, however poly I:C did not produce any affect (B-1). Nitrite release in the vehicle condition was not affected by MAPK inhibition (B-2), but JNK-IN-8 and ERK inhibition under the LPS condition reduced nitrite release, whilst (B-3) p38 inhibition with resiquimod increased iNOS production. Griess assay

Cxcl10 mRNA starting more slowly, there was a much greater response to LPS by $24 \mathrm{~h}$. The same greater response to LPS compared to resiquimod was seen with $C c l 5$ mRNA (Fig. 5C). CCL 2 protein release broadly reflected mRNA level changes even though it showed a later induction time point (Fig. 5B). CCL5 and CXCL10 protein levels, despite the mRNAs changing over time, did not show any increases (Fig. 5D,F). Our results suggest that bacterial infection will result in relatively greater chemokine (CCL5, CXCL10) release, and relatively less cytokine (IL-6, TNF $\alpha$ ) release, from microglia, compared to single-stranded virus infection. These findings emphasise that protein level does not always reflect mRNA level, and other factors may influence the amount of protein that is detectable. Moreover, the nature of the immune response will clearly be different, depending on the pathogen.

\section{Effect of MAPK Inhibitors on Cytokine and Chemokine Induction}

To determine the effect of MAP kinase inhibition on cytokine and chemokine secretion, the cells were pre-treated was performed and the individual data points are shown along with mean \pm SEM. The data were analysed by two-way ANOVA, Tukey post hoc test $(* p \leq 0.05, * * p \leq 0.005, * * * p \leq 0.001, * * * * p \leq 0.0001$ vs. same TLR activator without inhibitors, Tukey comparisons; ${ }^{\ddagger} p \leq 0.05,{ }^{\neq \neq} p \leq 0.005,{ }^{\neq \neq \neq} p \leq 0.001,{ }^{\neq \neq \neq \neq} p \leq 0.0001$ Resiquimod vs. SB203580 within resiquimod treatment group one-way ANOVA Bonferroni post hoc test). Vehicle $(\mathrm{V})$ data in $\mathbf{B - 2}$ and $\mathbf{B - 3}$ are repeated data from Vehicle(V) in B-1. ( $n=8-24$ /group). Details of ANOVA $F$ values and $p$ values are provided in Supplementary Information

with MAPK inhibitors, JNK-IN-8, PD98059, or SB203580, and then stimulated with LPS or resiquimod. After $8 \mathrm{~h}$, LPS and resiquimod induced $I l-6$ mRNA, and minor effects of MAPK inhibition were seen under resiquimod stimulation (Fig. 6A-C). IL-6 release with LPS or resiquimod was not detectable (data not shown). In contrast to Il-6 mRNA, Tnf mRNA showed MAPK inhibition effects. The levels of Tnf mRNA were altered by ERK inhibition with vehicle and LPS $(\mathrm{F}(3,18)=24.33, p<0.0001$; LPS vs. LPS+PD98059, $p=0.0079$; LPS vs, LPS+SB203580, $p=0.0002$, Bonferroni post hoc) but with resiquimod, however, JNK inhibition did not cause any alterations of Tnf mRNA (Fig. 6D-F). In spite of the alteration of $T N F$ mRNA levels, TNF protein did not reflect these changes (Fig. $6 \mathrm{G}, \mathrm{H}$ ). In contrast to the lack of effect of JNK inhibition on Tnf mRNA induction by resiquimod, the increased TNF protein release was clearly inhibited (Fig. 6I). These results emphasise further the complex relationship between mRNA induction and protein release, and the distinct signalling pathways recruited in microglial cells by TLR4 and TLR7 stimulation (see Supplementary Figure 3). 

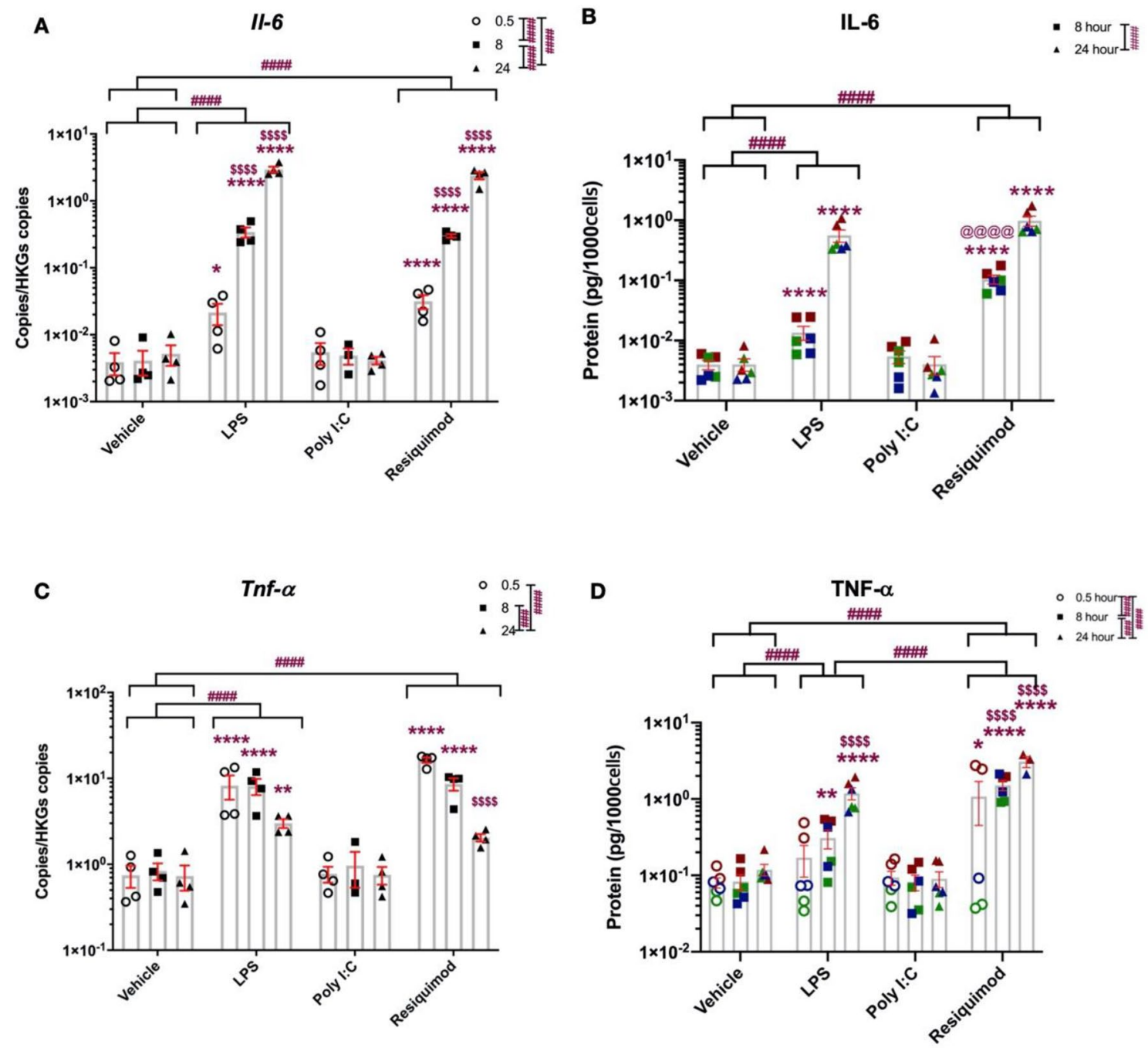

Fig. 4 Distinct time courses of TNF and IL-6 induction after LPS and resiquimod. The microglial cells were cultured in serum-free medium overnight, stimulated by LPS $(50 \mathrm{ng} / \mathrm{ml})$, poly I:C (100 ng/ $\mathrm{ml})$, or resiquimod $(3 \mu \mathrm{M})$, and RNA extracted and the culture media stored after the times indicated. A $I l-6$ mRNA showed meaningful changes from $8 \mathrm{~h}$ stimulation with LPS and resiquimod but not with poly I:C. B IL-6 release increased statistically from 8 and $24 \mathrm{~h}$ stimulation with LPS and resiquimod. $0.5 \mathrm{~h}$ stimulation data were below quantification limit. C $T n f$ mRNA was maximally increased at $0.5 \mathrm{~h}$ after stimulation with LPS or resiquimod. D TNF release was significantly increased from $8 \mathrm{~h}$ and this level continued to increase. The individual data points are shown along with mean \pm SEM. The

Similarly complex regulation was observed with proinflammatory chemokines after MAPK inhibition. Under the vehicle condition, MAPK inhibition effects on $\mathrm{Ccl} 2$ mRNA and CCL2 protein were not detected (Fig. 7A, D), but there was other evidence for JNK involvement in the regulation of CCL2 release, in that JNK inhibition increased the stimulatory effect of LPS, but not resiquimod (Fig. 7E, F). LPS stimulation increased $C c l 2$ mRNA levels, which was further enhanced with p38 inhibition

colour represent passages of the cells. Data were analysed by twoway ANOVA (RT-qPCR); or three-way ANOVA (ELISA), Tukey post hoc test $(n=4-6$ independent samples; $* p \leq 0.05, * * p \leq 0.005$, $* * * p \leq 0.001, * * * * p \leq 0.0001$ vs. vehicle control at same stimulation time; ${ }^{\$} p \leq 0.05,{ }^{\$ \$} p \leq 0.005,{ }^{\$ \$} p \leq 0.001,{ }^{\$ \$ \$} p \leq 0.0001$ vs. $0.5 \mathrm{~h}$ stimulation within the same treatment group; ${ }^{\#} p \leq 0.05,{ }^{\# \#} p \leq 0.005$,

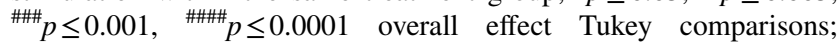
${ }^{@} p \leq 0.05$, @ @ $p \leq 0.005$, @@@ $p \leq 0.001$, @@@@ $p \leq 0.0001$ LPS vs. resiquimod in a same stimulation time Tukey comparisons). ( $n=4-6 /$ group). Details of ANOVA $F$ values and $p$ values and of Fisher-Pitman permutation testing are provided in Supplementary Table 2

(Fig. 7B); however, this change was also not detectable in protein level (Fig. 7E). As observed previously, LPS produced a greater induction of $\mathrm{Ccl} 5$ and $\mathrm{Cxcl} 10$ mRNA than resiquimod. $C c l 5$ mRNA was not affected by any MAPK inhibitor (Fig. 7G-I). CCL5 protein levels were not significantly changed (Fig. 7J-L). However, JNK inhibition with LPS induced CCL5 protein levels $(\mathrm{F}(3,16)=7.917$, $p=0.0018$; LPS vs. LPS+JNK-IN- $8, p=0.0014$; Bonferroni post hoc) and its secretion pattern is similar to CCL2 

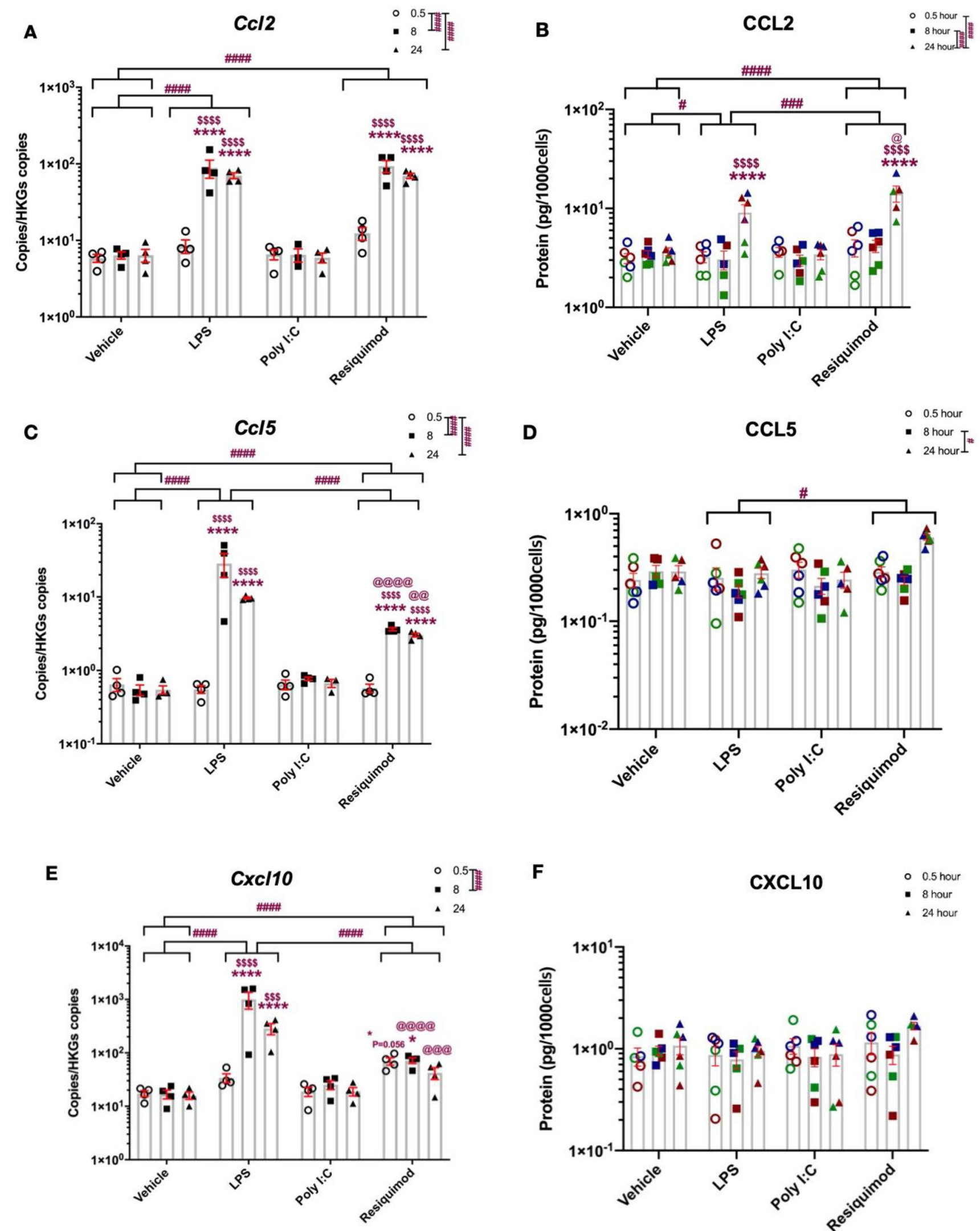

F

CXCL10

- 0.5 hour

- 8 hour

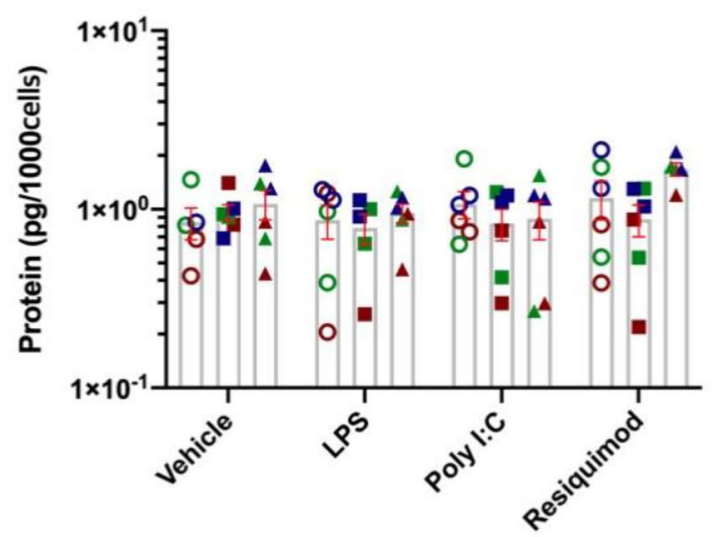


4Fig. 5 Distinct chemokine induction after LPS and resiquimod. The microglial cells were cultured in serum-free medium overnight, stimulated by LPS $(50 \mathrm{ng} / \mathrm{ml})$, poly I:C $(100 \mathrm{ng} / \mathrm{ml})$, or resiquimod ( $3 \mu \mathrm{M}$ for the times indicated. A Ccl 2 mRNA levels were increased by LPS and resiquimod after $8 \mathrm{~h}$ stimulation but not by poly I:C. B CCL2 protein level showed meaningful changes with LPS and resiquimod stimulation at $24 \mathrm{~h}$. C Ccl5 mRNA showed considerable changes after $8 \mathrm{~h}$ resiquimod stimulation and its level remained increased till $24 \mathrm{~h}$. LPS challenge induced an even greater increase in Ccl5 mRNA levels from 8 and $24 \mathrm{~h}$. D CCL5 protein levels did not change. E Cxcl10 mRNA increased from $8 \mathrm{~h}$ after stimulation with LPS. Resiquimod showed a lesser induction from $0.5 \mathrm{~h}$ and its level was no different from control levels by $24 \mathrm{~h}$. F CXCL10 protein levels did not change at any timepoints with any treatments. The individual data points are shown along with mean \pm SEM. The colour represent passages of the cells. The data were analysed by two-way ANOVA (RT-qPCR); three-way ANOVA (ELISA), Tukey post hoc test $(n=4-6$ independent samples; $* p \leq 0.05, * * p \leq 0.005$, $* * * p \leq 0.001, * * * * p \leq 0.0001$ vs. vehicle control at same stimulation time; ${ }^{\$} p \leq 0.05,{ }^{\$ \$} p \leq 0.005,{ }^{\$ \$} p \leq 0.001,{ }^{\$ \$ \$} p \leq 0.0001$ vs. $0.5 \mathrm{~h}$ stimulation within the same treatment group; ${ }^{*} p \leq 0.05,{ }^{\# \#} p \leq 0.005$,

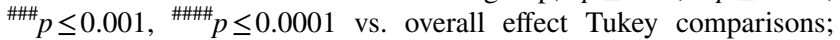

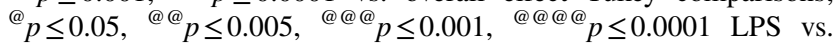
resiquimod in a same stimulation time Tukey comparisons). ( $n=4-6 /$ group). Details of ANOVA $F$ values and $p$ values and of Fisher-Pitman permutation testing are provided in Supplementary Table 2

protein (Fig. 7E, K). Interestingly, p38 inhibition increased the $C c l 5$ mRNA and CCL5 protein response to resiquimod (Fig. 7I, L). Cxcl10 mRNA was not meaningfully changed by any MAPK inhibition (Fig. 7M-O). CXCL10 protein levels were below the threshold for detection (data not shown). These observations may suggest that MAPKs are not crucial, but selectively participate in chemokine induction during immune responses of microglia (see Supplementary Figure 3).

Many previous studies of the effects of JNK inhibition on the cytokine or chemokine responses in immune cells use the JNK inhibitor SP600125, which is fairly, but not completely selective for JNKs (Bain et al. 2007). When we compare the effects of SP600125 (at a widely used and putatively JNK-selective concentration) with the highly selective inhibitor JNK-IN-8 used here (Zhang et al. 2012) we observed some very clear differences between them (Supplementary Figure 3).

\section{Discussion}

Through a direct comparison of the effects and mechanisms of different immune stimuli, we have found that the microglial cells studied here have very little response to TLR3 stimulation, distinct responses to TLR4 and TLR7 activation, and also a complex and distinct contribution of MAP kinase pathways to the regulation of the immune response.

\section{Lack of Response to polylC}

We detected clear MAP kinase/cytokine/chemokine responses to relatively low concentrations of LPS and resiquimod, with induction of all of the cytokines/ chemokines measured. However, the general lack of responsiveness to polyI:C was surprising. The poly I:C employed clearly acts as a TLR3 stimulant, as we have previously observed substantial in vivo systemic immune responses to this batch of poly $\mathrm{I}: \mathrm{C}$ in mice (Openshaw et al. 2019). The concentration of poly I:C used here in vitro-100 ng/ $\mathrm{ml}$ - has previously been reported to activate p38 and JNK signalling in primary rat microglial cultures (de Oliveira et al. 2016), and to induce a large enhancement of cytokine release from microglia and other cells (Remels et al. 1990; Ribes et al. 2010; Peltier et al. 2010; Lehmann et al. 2012) via TLR3 stimulation. However, cytokine induction and JNK activation with a much higher (500x) poly I:C concentration are not mediated by TLR3 (Town et al. 2006).

Consistent with our data, many studies have reported a lack of response, or very low sensitivity, to poly $\mathrm{I}$ :C, in microglial cells (Olson and Miller 2004; Zuiderwijk-Sick et al. 2007; Lobo-Silva et al. 2017), and in peripheral blood mononuclear cells, where the cytokine and chemokine responses to poly I:C are 100-1000-fold smaller than the responses to TLR4 or TLR7/8 $(2.5 \mu \mathrm{M}$ resiquimod) stimulation (Ghosh et al. 2006; Monguió-Tortajada et al. 2018).

The expression of TLR3 in SIM-A9 cells was substantially lower than that of TLR4 and TLR7. Primary primate microglial cells also express very low levels of TLR3 (Zuiderwijk-Sick et al. 2007). A possible explanation for the discrepant findings on poly I:C sensitivity may be that TLR3 expression is highly dynamic, with marked transcriptional induction depending on the degree of prior activation of the immune cells (Olson and Miller 2004; Town et al. 2006; Monguió-Tortajada et al. 2018). It seems likely that the SIM-A9 cells under our conditions are in a quasi-resting condition, with low basal Tlr3 mRNA expression, possibly reflecting the lack of extensive and prolonged isolation procedures used for primary cultures, or viral imortalisation as in other microglial cell lines. Our data therefore support a growing awareness that sensitivity to TLR3 stimulation of microglia in their resting state may be rather limited.

\section{Relative Responses to TLR4 and TLR7 Stimulation- MAP Kinase Activation}

Exposure of SIM-A9 microglial cells to LPS or resiquimod led to a rapid and pronounced phosphorylation of JNKs and p38s, with JNK activation being especially dramatic. Phosphorylation (activation) of ERKs 1 and 2 (p44 and p42 ERK) appeared to occur after a slight delay relative to the phosphorylation of JNKs and p38 MAP kinases. 


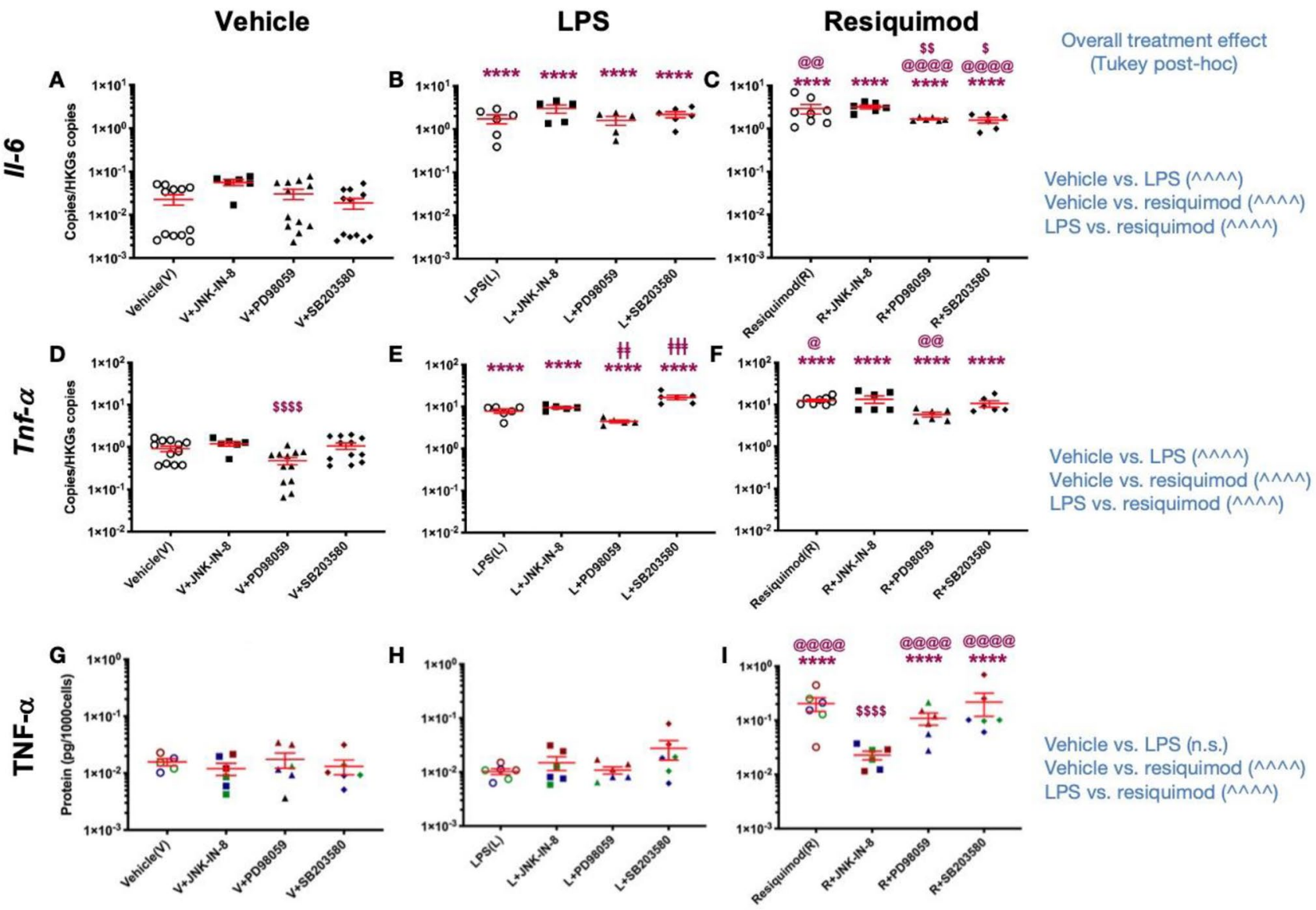

Fig. 6 Pro-inflammatory cytokines are selectively regulated by MAPKs in microglia after LPS and resiquimod. The microglial cells were cultured in the serum-free medium and left overnight. The cells were stimulated by LPS $(50 \mathrm{ng} / \mathrm{ml})$ or resiquimod $(3 \mu \mathrm{M})$ for $8 \mathrm{~h}$ and MAPK inhibitors, JNK (JNK-IN-8, JNK inhibitor, $1 \mu \mathrm{M}$ ), ERK (PD98059, ERK inhibitor, $40 \mu \mathrm{M}$ ), or p38 (SB203580, p38 inhibitor, $5 \mu \mathrm{M}$ ), or vehicle, were added before the mimetics. A-C Il-6 mRNAs did not show any MAPKs' inhibitor effects compare to vehicle or LPS only condition. ERK and p38 inhibition suppressed Il-6 mRNA production when it combined with resiquimod. D-F Tnf mRNA did not any statistically significance of LPS or resiquimod with MAPKs' inhibitors. G-I TNF-a proteins were only changed by JNK inhibitor with resiquimod. Absolute quantification was performed via RT-qPCR and the data were normalised to Gapdh and Henmt1. Total amount of protein (per 1000 cells) was presented on

This is consistent with a report that primary microglial cells show ERK activation peaking at 20-30 min after LPS exposure (Bhat et al. 1998). However, the clear ERK response to LPS in SIM-A9 cells as well as primary microglia is interesting, since the BV-2 mouse microglial cell line reportedly shows very little ERK activation at any time after LPS exposure (Watters et al. 2002). This probably reflects high basal levels of ERK activity, as these cells are immortalised by activation of this pathway (Blasi et al. 1990). graphs and its amount was measured by ELISA. The individual data points are shown along with mean \pm SEM. The colour represents passages of the cells. The data were analysed by three-way ANOVA, Tukey post hoc test $(n=5-12$ independent samples; $* p \leq 0.05$, $* * p \leq 0.005, * * * p \leq 0.001, * * * * p \leq 0.0001$ vs. vehicle under the same inhibitor; ${ }^{\$} p \leq 0.05,{ }^{\$} p \leq 0.005,{ }^{\$ \$} p \leq 0.001,{ }^{\$} \$ \$ p \leq 0.0001 \mathrm{vs}$. vehicle alone within the same immune mimetic group; ${ }^{\circledR} p \leq 0.05$,

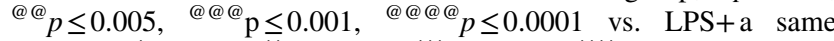
inhibitor; ${ }^{\wedge} p \leq 0.05,{ }^{\wedge} p \leq 0.005,{ }^{\wedge \wedge} p \leq 0.001,{ }^{\wedge \wedge \wedge} p \leq 0.0001$ overall treatment effects; ${ }^{\ddagger} p \leq 0.05,{ }^{\neq \neq} p \leq 0.005,{ }^{\neq \neq \neq} p \leq 0.001,{ }^{\neq \neq \neq \neq} p \leq 0.0001$ LPS vs. LPS+PD98059 and LPS vs. SB203580 within LPS treatment group one-way ANOVA Bonferroni post hoc test). ( $n=5-12 /$ group). Details of ANOVA $F$ values and $p$ values are provided in Supplementary Information

\section{Relative Responses to TLR4 and TLR7 Stimulation- Cytokines}

Agonists at TLR7/8 are relatively poorly studied in microglial cells, in comparison to TLR3 or TLR4 agonists. We found that resiquimod was a powerful stimulant of cytokine and chemokine release, consistent with its effects on MAP kinase phosphorylation. Expression of TLR8, was relatively low, suggesting that the effects of resiquimod are mediated via TLR7 rather than TLR8. The strong responses that we 
observe following TLR7 activation, as compared to activation of TLR3, or even TLR4, are consistent with evidence that stimulation of cytokine (TNF) release from primary primate microglial cells is also especially sensitive to TLR7/8 agonists (Zuiderwijk-Sick et al. 2007). There is controversy with primary mouse microglia, which have been reported to be relatively unresponsive to TLR7 stimulation, compared to TLR4 stimulation, (Lee et al. 2016), or especially sensitive to the TLR7 stimulation (Butchi et al. 2008). These discrepancies again may relate to the degree of prior sensitisation of the cells. Our data are also consistent with data from mouse macrophages (Pauls et al. 2013) where $3 \mu \mathrm{M}$ resiquimod produces much greater increases in Tnf- $a$ mRNA compared to $100 \mathrm{ng} / \mathrm{ml}$ LPS.

It is interesting to note that $I l 6$ mRNA and IL- 6 protein induction develops relatively slowly, over $24 \mathrm{~h}$, in contrast Tnf- $a$ mRNA and TNF protein induction, which is detected in $0.5 \mathrm{~h}$, even though they are in the same functional group (pro-inflammatory cytokines). This has been noted in other systems (Eskay et al. 1990) and so is not unique to microglia.

\section{Relative Responses to TLR4 and TLR7 Stimulation- Chemokine Induction}

Cxcl10 mRNA induction after resiquimod is remarkably fast (mRNA is elevated after $0.5 \mathrm{~h}$ ), but then declines, in contrast to the slower but more sustained time course after LPS, and indeed the slower but more sustained time course after resiquimod for $\mathrm{Ccl} 2$ and $\mathrm{Ccl} 5 \mathrm{mRNAs}$. This is similar to the rapid induction of TNF mRNA, and, in terms of mechanism, at least partially reflects fast pre-mRNA splicing for these two genes (Hao and Baltimore 2013). Similar effects have been noted in vivo, where induction of Cxcl10 in vivo by Toxoplasma Gondii infection is faster than induction of $\mathrm{Ccl} 2 / \mathrm{Ccl} 5$ (Khan et al. 2000).

For most of the cytokine/chemokines monitored, the degree of induction by LPS and resiquimod was roughly equivalent, at the concentrations used. However, it was noticeable that the profile of the response differed, with LPS producing a greater induction of $\mathrm{Ccl} 5$ and $\mathrm{Cxcl} 10 \mathrm{mRNAs}$, whilst resiquimod produced a greater induction of Tnf, Il6 and $C c l 2$ mRNAs (Figs. 4, 5, 6, 7), indicative of distinct signalling pathways downstream of TLR4 and TLR7.

\section{Effects of p38 Kinase Inhibition}

Inhibition of p38 tended to facilitate nitrite production after TLR4 stimulation. In previous reports, SB203580 is often observed to diminish iNOS induction, or nitrite production in microglial cells (Pyo et al. 1998; Bhat et al. 1998; Watters et al. 2002; Han et al. 2002; Wen et al. 2011). However, in macrophage cells, selective p38 inhibition increases nitrite release following LPS exposure (Lahti et al. 2002, 2006), due to enhanced JNK signalling, normally dampened by a p38-mediated destabilisation of JNK. Since higher concentrations of SB203580 $(30 \mu \mathrm{M})$ inhibit nitrite production by a mechanism unrelated to p38 inhibition (Lahti et al. 2002), this may provide an explanation for some of the discrepant reports.

As predicted from other studies (Tessaro et al. 2017; Rutault et al. 2001), p38 inhibition reduced TNF release. However, we found no reduction in $T N F$ mRNA with p38 inhibition. In fact, mRNA levels were increased with p38 inhibition after LPS, but not resiquimod, treatment. This resembles the recently reported increased $T N F$ mRNA levels after p38 inhibition in epithelial cells, reflecting loss of a p38-mediated transcriptional induction of the TNF mRNA destabiliser tristetraprolin (Shah et al. 2016). Our data suggest the operation of a similar mechanism in microglia. These actions of p38 are likely to be very time-dependent, as p38 also rapidly suppresses tristetraprolin-mediated destabilisation of its target mRNAs via phosphorylation events (Ronkina et al. 2019; Prabhala et al. 2015). The overt post-transcriptional effects of $\mathrm{p} 38$ inhibition on TNF release probably reflect actions on TRIF (Gais et al. 2010), or MAPKAP-K2 (Kotlyarov et al. 1999; Tiedje et al. 2014).

It is interesting to note that the enhancing effect of p38 inhibition on TNF mRNA is also seen with $C c l 2$ and $C c l 5$ mRNA, as $C c l 2$ and $C c l 5$ mRNAs are also known to be tristetraprolin targets (Tu et al. 2019; Schichl et al. 2009; Ishmael et al. 2008). Moreover, this p38 action is clearly both time- and pathogen-specific, and yet implies some commonality in the regulation of this group of genes.

\section{Effect of JNK and ERK Inhibition-Cytokine and Nitric Oxide Production}

Inhibition of JNK or ERK suppressed immune mimeticstimulated nitric oxide and TNF release. The effect on nitric oxide was more pronounced with LPS, whilst the effect on TNF was more pronounced with resiquimod. ERK inhibition, but not JNK inhibition, also decreased TNF mRNA induction by stimulation of both TLR4 and TLR7. Induction of IL-6 was less dramatic than TNF, but this may reflect the time point chosen, and the slower induction of $I l-6 \mathrm{mRNA}$ compared to TNF mRNA (Fig. 3).

The suppression of microglial nitric oxide release, following exposure to LPS or resiquimod, by inhibition of ERK or JNK pathways, has been shown in a number of previous studies, both in microglia, and in other immune response cells (Bhat et al. 1998; Pyo et al. 1998; Lahti et al. 2003; Wang et al. 2004; Yu et al. 2017). ERK and JNK are also generally reported to mediate increased TNF release in response to LPS (Swantek et al. 1997; Scherle et al. 1998; Zhu et al. 2000; Wang et al. 2004, 2010; Sánchez-Tilló et al. 2007). The lack of suppression 
Vehicle

A
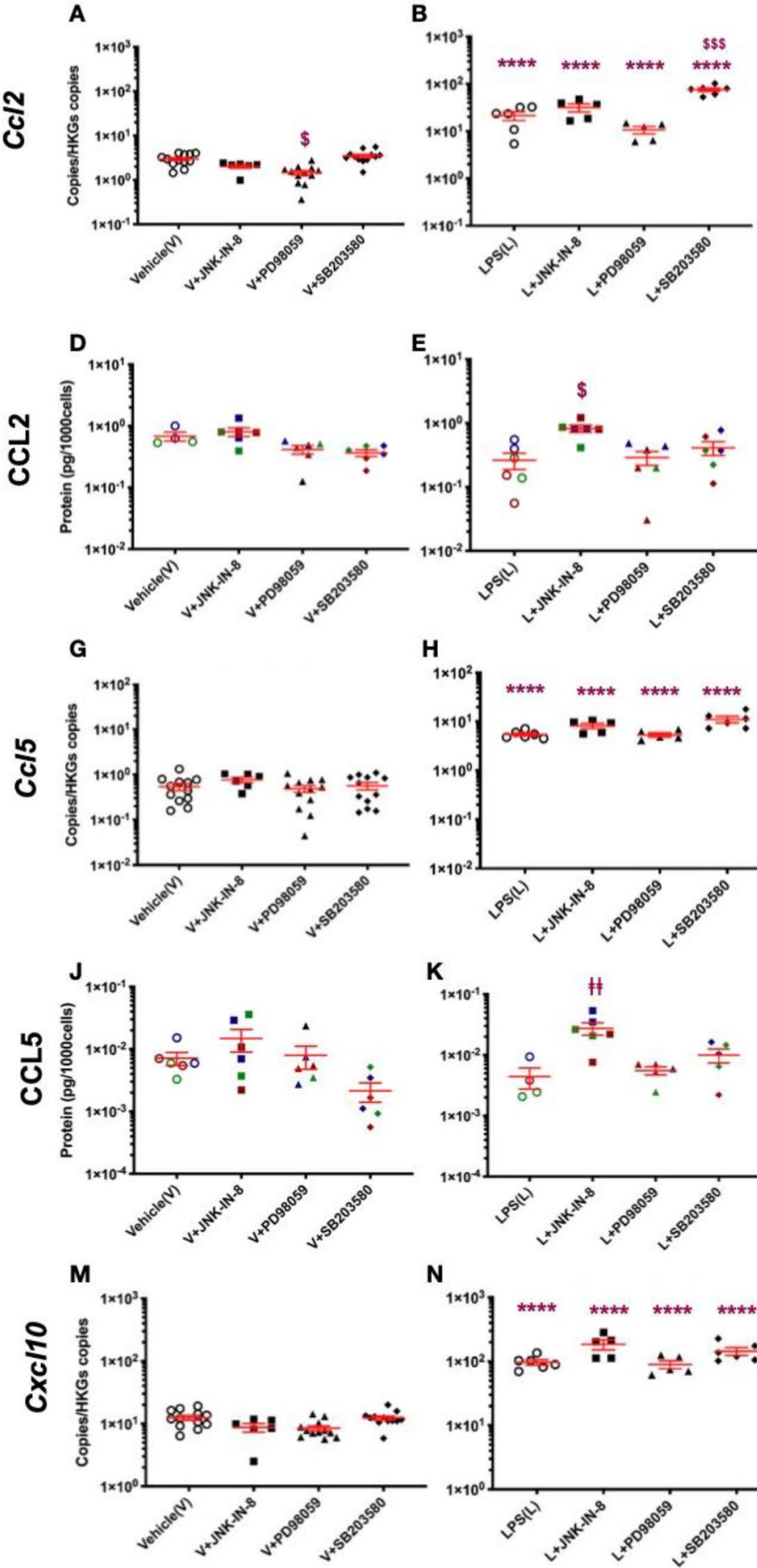

H
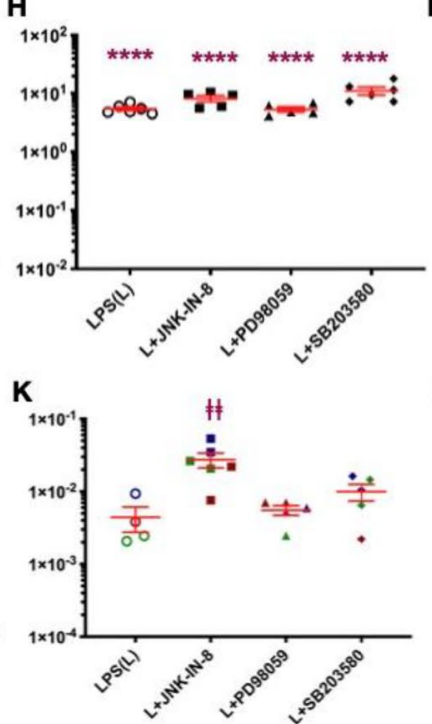

$\mathbf{N}$

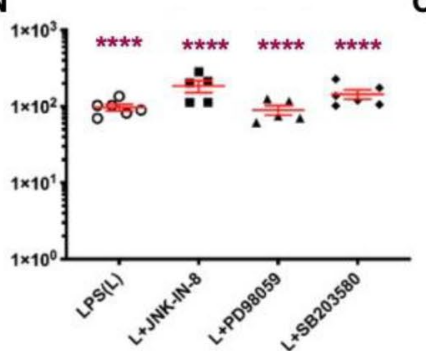

\section{Resiquimod}

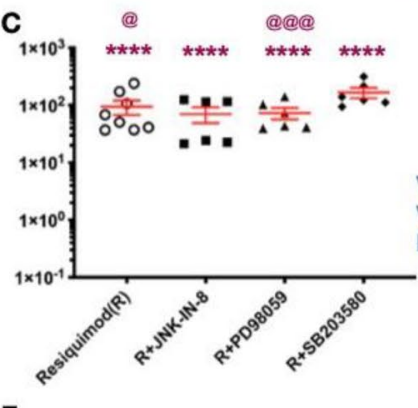

verall treatment effect

(Tukey post-hoc)

$\mathbf{F}$
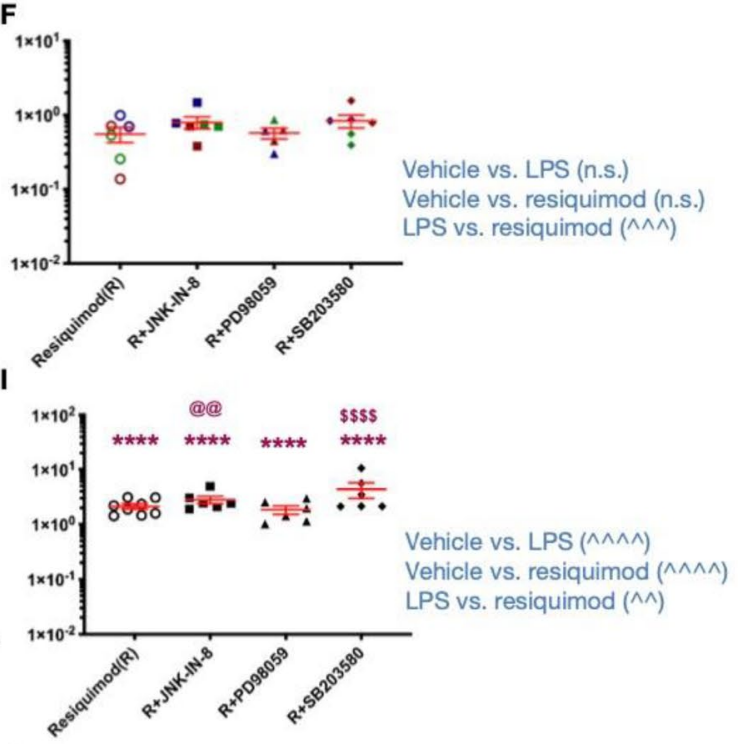

$\mathbf{L}$

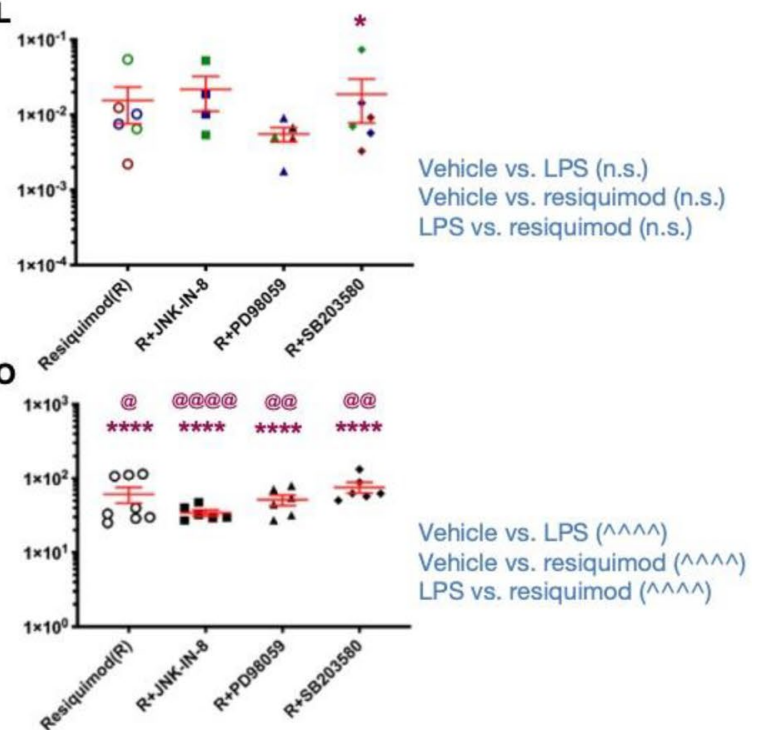

of TNF release by inhibition of JNK pathways reported here, following exposure to LPS, was not predicted; the more so considering that inhibiting JNK does suppress the response to resiquimod (summarised in Supplementary Figure 3). To understand the role of JNK following TLR7, but not TLR4, stimulation, it is worth noting that TRAF6 may contribute to signalling by the former but not the latter (Loniewski et al. 2007), and that TRAF6 mediates JNK activation in various cell types (Kobayashi et al. 2001; Wan et al. 2004). 
4Fig.7 MAPKs selectively affect inflammatory chemokine in microglia after immune challenges. The cells were cultured in the serum-free medium and left overnight. The cells were stimulated by LPS $(50 \mathrm{ng} / \mathrm{ml})$ or resiquimod $(3 \mu \mathrm{M})$ for $8 \mathrm{~h}$ and MAPK inhibitors, JNK (JNK-IN-8, JNK inhibitor, $1 \mu \mathrm{M}$ ), ERK (PD98059, ERK inhibitor, $40 \mu \mathrm{M}$ ), or p38 (SB203580, p38 inhibitor, $5 \mu \mathrm{M}$ ), were added before the mimetics. A-C $C c l 2$ mRNA, D-F CCL2 protein, G-I Ccl5 mRNA, J-L CCL5 protein, M-O Cxcl10 mRNA. Absolute quantification was performed via RT-qPCR and the data were normalised to Gapdh and Henmtl. Total amount of protein (per 1000 cells) is shown. The individual data points are shown along with mean \pm SEM. The colour represents passages of the cells. The data were analysed by three-way ANOVA, Tukey post hoc test $(n=5-12$ independent samples; $* p \leq 0.05$, ** $p \leq 0.005$, *** $p \leq 0.001$, $* * * * p \leq 0.0001$ vs. vehicle under a same inhibitor; ${ }^{\$} p \leq 0.05$, $\$ \$ p \leq 0.005,{ }^{\$ \$} p \leq 0.001,{ }^{\$ \$ \$} p \leq 0.0001$ vs. vehicle alone within the

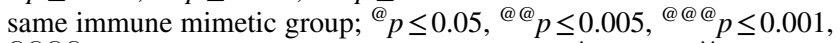
@@@@ $p \leq 0.0001$ vs. LPS + the same inhibitor; ${ }^{\wedge} p \leq 0.05,{ }^{\wedge \wedge} p \leq 0.005$, ${ }^{\wedge \wedge} p \leq 0.001,{ }^{\wedge \wedge} p \leq 0.0001$ overall treatment effects; ${ }^{\ddagger} p \leq 0.05$, ${ }^{\ddagger \neq} p \leq 0.005,{ }^{\neq \neq \neq} p \leq 0.001,{ }^{\neq \neq \neq \neq} p \leq 0.0001$ LPS vs. LPS + JNK-IN-8 within LPS treatment group one-way ANOVA Bonferroni post hoc test). ( $n=5-12 /$ group). Details of ANOVA $F$ values and $p$ values are provided in Supplementary Information

\section{Effect of JNK and ERK Kinase Inhibition- Chemokine Production}

Selective inhibition of JNK enhanced the release of CCL2 by LPS, but not by resiquimod. Again this illustrates the selectivity with which distinct TLRs recruit distinct signalling pathways, and reveals that JNK can suppress CCL2 release.

We noted above that the enhancing effect of p38 inhibition on Tnf, $C c l 2$ and $C c l 5$ mRNAs implied some commonality in the regulation of this group of genes. However, whilst $C c l 5$ showed a larger induction by TLR 4 compared to TLR7 stimulation, this was also true for $\mathrm{Cxcl10}$, but not for $C c l 2$ (Figs. 5, 7). JNK inhibition further enhances Cxcl10 responses to LPS but not resiquimod (as indeed it enhances TNF response to resiquimod but not LPS). This effect of JNK is despite the larger LPS responses noted above, suggesting additional (JNK-mediated) mechanisms may be recruited to dampen the powerful $\mathrm{Cxcl10}$ response to TLR4 stimulation.

There are a number of contradictory findings concerning the extent to which ERK, p38 and JNK mediate induction of CCL2, CCL5 and CXCL10 release from microglia and other immune cells (Aversa et al. 2004; Nakamichi et al. 2005; Bandow et al. 2012). Some of these discrepancies may reflect differential control of mRNA versus protein, as noted above.

Much of the confusion in the literature regarding the effects of JNK inhibition on the immune response no doubt reflects the use of SP600125, which is fairly, but not completely selective for JNKs. Indeed, when we compare the effects of SP600125 (at a putatively JNK-selective concentration) with the highly selective inhibitor JNK-IN-8 (Zhang et al. 2012) we observed some fairly dramatic differences
(Supplementary Figure 3). SP6001265, at a concentration sufficient to inhibit JNKs, will also inhibit various kinases including SGK1 and PKD1 (Bain et al. 2007), which likely contribute to the variable results obtained in other studies.

It is notable from our data that $\mathrm{p} 38$ regulates $\mathrm{Ccl} 2$ and Ccl5 at the mRNA level whilst JNK acts at the post-transcriptional level. Similar effects are seen with TNF (Supplementary Figures 3). The dramatically differing effects on mRNA vs protein of JNK and p38, whilst supported by prior reports, are not easily understood in terms of the functional significance. It may be that the post-transcriptional control allows a "fine tuning" of the courser control provided by transcriptional regulation (rheostat vs switch), and it has been proposed that a wider dynamic range is generally observed for protein as compared to mRNA (Vogel and Marcotte 2012). Our results therefore implicate JNK in this fine tuning of microglial responses, and p38 rather in broad control. Indeed, where the magnitude of the response to TLR4 and TLR7 stimulation differs, this seems to be due to the selective activation of a p38-mediated suppression of mRNA levels in the lower of the responses (Supplementary Figure 3).

\section{Conclusions}

The data show that TLR3 stimulation has little effect on MAP kinase activation or cytokine/chemokine responses in resting microglial cells. TLR4 and TLR7 stimulation produces clear effects, but the profile of cytokine/chemokine induction differs between them, as do the signalling pathways involved. With the exception of TNF release, inhibition of ERK, JNK or p38 had surprisingly little effect to suppress cytokine or chemokine induction, and in some specific instances actually enhanced the effects of LPS or resiquimod.

The question remains, if MAP kinase pathways are exerting subtle modulatory effects on the microglial inflammatory response, then what signalling pathway is responsible for the main gene induction events downstream of TLR stimulation? The most likely candidate is the NF-kappaB pathway, which a wide range of evidence implicates in microglial activation alongside MAPK pathways (Kaminska et al. 2016). Indeed, there is evidence that LPS is much more effective than poly I:C at activating NF-kappaB in human macrophages (Reimer et al. 2008). It is also worth considering the possibility that simultaneous combined inhibition of all three major MAP kinase pathways (ERK, JNK and p38), might produce a qualitatively greater suppression of inflammatory mediator induction than individual inhibition of each component. However, current evidence suggests that interactions between the different kinase cascades tend to be negative feedback cross-regulation rather than synergistic 
downstream actions (Junttila et al. 2008; Boutros et al. 2008), and where inhibitors of different MAPK pathways have been applied in combination, synergistic inhibitory effects have not been observed (Dolivo et al. 2019).

The effect of p38 inhibition to enhance rather than suppress mRNA induction of some inflammatory mediators may be highly relevant for the current development of $\mathrm{p} 38$ inhibitors as therapeutic agents for neurodegenerative and psychiatric disease (Scheltens et al. 2018; Wittenberg et al. 2019). Furthermore, our results suggest that infection with single-stranded viruses will produce much greater microglial TNF release than bacterial infection. In any situation where JNK activity is elevated (as for example in genetic predisposition to schizophrenia (Winchester 2012), this induction of TNF $\alpha$ will be even further increased. This may be highly relevant for understanding the basis of the increased risk of schizophrenia caused by antenatal viral infections.

Supplementary Information The online version contains supplementary material available at https://doi.org/10.1007/s10571-021-01127-x.

Acknowledgements We would like to thank John Craig for excellent technical support.

Funding The research leading to these results received funding from the Wellcome Trust under Grant reference 104025/Z/14/Z.

Data Availability The datasets generated during and/or analysed during the current study are available from the corresponding author on reasonable request.

\section{Declarations}

Conflicts of interests The authors have no relevant financial or nonfinancial interests to disclose.

Open Access This article is licensed under a Creative Commons Attribution 4.0 International License, which permits use, sharing, adaptation, distribution and reproduction in any medium or format, as long as you give appropriate credit to the original author(s) and the source, provide a link to the Creative Commons licence, and indicate if changes were made. The images or other third party material in this article are included in the article's Creative Commons licence, unless indicated otherwise in a credit line to the material. If material is not included in the article's Creative Commons licence and your intended use is not permitted by statutory regulation or exceeds the permitted use, you will need to obtain permission directly from the copyright holder. To view a copy of this licence, visit http://creativecommons.org/licenses/by/4.0/.

\section{References}

Autret A, Martin-Latil S, Brisac C, Mousson L, Colbère-Garapin F, Blondel B (2008) Early phosphatidylinositol 3-kinase/Akt pathway activation limits poliovirus-induced JNK-mediated cell death. J Virol 82(7):3796-3802. https://doi.org/10.1128/JVI. 02020-07
Aversa TGD, Yu KOA, Berman JW (2004) Expression of chemokines by human fetal microglia after treatment with the human immunodeficiency virus type 1 protein Tat. J Neurovirol 10(2):86-97. https://doi.org/10.1080/13550280490279807

Bain J, Plater L, Elliott M, Shpiro N, Hastie CJ, Mclauchlan H, Klevernic I, Arthur JSC, Alessi DR, Cohen P (2007) The selectivity of protein kinase inhibitors: a further update. Biochem $\mathrm{J}$ 408(3):297-315. https://doi.org/10.1042/BJ20070797

Bandow K, Kusuyama J, Shamoto M, Kakimoto K, Ohnishi T, Matsuguchi T (2012) LPS-induced chemokine expression in both MyD88-dependent and-independent manners is regulated by Cot/ Tpl2-ERK axis in macrophages. FEBS Lett 586(10):1540-1546. https://doi.org/10.1016/j.febslet.2012.04.018

Baufeld C, O'Loughlin E, Calcagno N, Madore C, Butovsky O (2018) Differential contribution of microglia and monocytes in neurodegenerative diseases. J Neural Transm 125(5):809-826. https:// doi.org/10.1007/s00702-017-1795-7

Beckham JD, Goody RJ, Clarke P, Bonny C, Tyler KL (2007) Novel strategy for treatment of viral central nervous system infection by using a cell-permeating inhibitor of c-Jun $\mathrm{N}$-terminal kinase. J Virol 81(13):6984-6992. https://doi.org/10.1128/JVI.00467-07

Bhat NR, Zhang P, Lee JC, Hogan EL (1998) Extracellular signalregulated kinase and $\mathrm{p} 38$ subgroups of mitogen-activated protein kinases regulate inducible nitric oxide synthase and tumor necrosis factor- $\alpha$ gene expression in endotoxin-stimulated primary glial cultures. J Neurosci 18(5):1633-1641. https://doi.org/10. 1523/JNEUROSCI.18-05-01633.1998

Blasi E, Barluzzi R, Bocchini V, Mazzolla R, Bistoni F (1990) Immortalization of murine microglial cells by a v-raf/v-myc carrying retrovirus. J Neuroimmunol 27(2-3):229-237. https://doi.org/10. 1016/0165-5728(90)90073-V

Boutros T, Chevet E, Metrakos P (2008) Mitogen-activated protein (MAP) kinase/MAP KINASE phosphatase regulation: roles in cell growth, death, and cancer. Pharmacol Rev 60(3):261-310. https://doi.org/10.1124/pr.107.00106

Bsibsi M, Ravid R, Gveric D, van Noort JM (2002) Broad expression of toll-like receptors in the human central nervous system. J Neuropathol Exp Neurol 61(11):1013-1021. https://doi.org/10. 1093/jnen/61.11.1013

Butchi NB, Pourciau S, Du M, Morgan TW, Peterson KE (2008) Analysis of the neuroinflammatory response to TLR7 stimulation in the brain: comparison of multiple TLR7 and/or TLR8 agonists. J Immunol 180(11):7604-7612. https://doi.org/10.4049/jimmu nol.180.11.7604

Butovsky O, Jedrychowski MP, Moore CS, Cialic R, Lanser AJ, Gabriely G, Koeglsperger T, Dake B, Wu PM, Doykan CE, Fanek Z, Liu L, Chen Z, Rothstein JD, Ransohoffl RM, Gygi SP, Antel JP, Weiner HL (2014) Identification of a unique TGF-beta dependent molecular and functional signature in microglia. Nat Neurosci 17(1):131-143. https://doi.org/10.1038/nn.3599

Cliffe Anna R, Arbuckle Jesse H, Vogel Jodi L, Geden Matthew J, Rothbart Scott B, Cusack Corey L, Strahl Brian D, Kristie Thomas M, Deshmukh M (2015) Neuronal stress pathway mediating a histone methyl/phospho switch is required for herpes simplex virus reactivation. Cell Host Microbe 18(6):649-658. https://doi.org/10.1016/j.chom.2015.11.007

Coffey ET (2014) Nuclear and cytosolic JNK signalling in neurons. Nat Rev Neurosci 15(5):285-299. https://doi.org/10.1038/nrn3729

Crews L, Patrick C, Achim C, Everall I, Masliah E (2009) Molecular pathology of neuro-AIDS (CNS-HIV). Int J Mol Sci 10(3):10451063. https://doi.org/10.3390/ijms10031045

Das A, Kim SH, Arifuzzaman S, Yoon T, Chai JC, Lee YS, Park KS, Jung KH, Chai YG (2016) Transcriptome sequencing reveals that LPS-triggered transcriptional responses in established microglia BV2 cell lines are poorly representative of primary 
microglia. J Neuroinflamm 13(1):182. https://doi.org/10.1186/ s12974-016-0644-1

Davis RJ (2000) Signal transduction by the JNK group of MAP kinases. Cell 103(2):239-252. https://doi.org/10.1016/s00928674(00)00116-1

de Oliveira ACP, Yousif NM, Bhatia HS, Hermanek J, Huell M, Fiebich BL (2016) Poly (I: C) increases the expression of mPGES-1 and COX-2 in rat primary microglia. J Neuroinflamm 13(1):11. https://doi.org/10.1186/s12974-015-0473-7

Del Villar K, Miller CA (2004) Down-regulation of DENN/MADD, a TNF receptor binding protein, correlates with neuronal cell death in Alzheimer's disease brain and hippocampal neurons. Proc Natl Acad Sci USA 101(12):4210-4215. https://doi.org/10. 1073/pnas.0307349101

Dolivo DM, Larson SA, Dominko T (2019) Crosstalk between mitogen-activated protein kinase inhibitors and transforming growth factor- $\beta$ signaling results in variable activation of human dermal fibroblasts. Int J Mol Med 43(1):325-335. https://doi.org/10.3892/ijmm.2018.3949

Dong C, Davis RJ, Flavell RA (2002) MAP kinases in the immune response. Annu Rev Immunol 20(1):55-72. https://doi.org/10. 1146/annurev.immunol.20.091301.131133

Efthymiou AG, Goate AM (2017) Late onset Alzheimer's disease genetics implicates microglial pathways in disease risk. Mol Neurodegener 12(1):43. https://doi.org/10.1186/ s13024-017-0184-x

Eskay RL, Grino M, Chen HT (1990) Interleukins, signal transduction, and the immune system-mediated stress response. Circulating regulatory factors and neuroendocrine function. Springer, Boston, pp 331-343. https://doi.org/10.1007/978-1-4684-5799-5_21

Fillman SG, Cloonan N, Catts VS, Miller LC, Wong J, McCrossin T, Cairns M, Weickert CS (2013) Increased inflammatory markers identified in the dorsolateral prefrontal cortex of individuals with schizophrenia. Mol Psychiatry 18(2):206-214. https://doi.org/10. 1038/mp.2012.110

Gais P, Tiedje C, Altmayr F, Gaestel M, Weighardt H, Holzmann B (2010) TRIF signaling stimulates translation of TNF- $\alpha$ mRNA via prolonged activation of MK2. J Immunol 184(10):58425848. https://doi.org/10.4049/jimmunol.0902456

Ghosh TK, Mickelson DJ, Fink J, Solberg JC, Inglefield JR, Hook D, Gupta SK, Gibson S, Alkan SS (2006) Toll-like receptor (TLR) 2-9 agonists-induced cytokines and chemokines: I. Comparison with $\mathrm{T}$ cell receptor-induced responses. Cell Immunol 243(1):48-57. https://doi.org/10.1016/j.cellimm.2006.12.002

Guilding C, McNair K, Stone TW, Morris BJ (2007) Restored plasticity in a mouse model of neurofibromatosis type 1 via inhibition of hyperactive ERK and CREB. Eur J Neurosci 25(1):99-105. https://doi.org/10.1111/j.1460-9568.2006.05238.x

Han I-O, Kim K-W, Ryu JH, Kim W-K (2002) p38 mitogen-activated protein kinase mediates lipopolysaccharide, not interferon- $\gamma,-$ induced inducible nitric oxide synthase expression in mouse BV2 microglial cells. Neurosci Lett 325(1):9-12. https://doi.org/10. 1016/S0304-3940(02)00218-5

Hao S, Baltimore D (2013) RNA splicing regulates the temporal order of TNF-induced gene expression. Proc Natl Acad Sci USA 110(29):11934-11939. https://doi.org/10.1073/pnas.1309990110

Hemmi H, Kaisho T, Takeuchi O, Sato S, Sanjo H, Hoshino K, Horiuchi T, Tomizawa H, Takeda K, Akira S (2002) Small anti-viral compounds activate immune cells via the TLR7 MyD88-dependent signaling pathway. Nat Immunol 3(2):196-200

Henn A, Lund S, Hedtjärn M, Schrattenholz A, Pörzgen P, Leist M (2009) The suitability of BV2 cells as alternative model system for primary microglia cultures or for animal experiments examining brain inflammation. Altex 26(2):83-94. https://doi.org/10. 14573/altex.2009.2.83
Herron JW, Nerurkar L, Cavanagh J (2018) Neuroimmune biomarkers in mental illness. Biomarkers in psychiatry. Springer, Cham, pp 45-78. https://doi.org/10.1007/7854_2018_45

Hong S, Lee EE, Martin AS, Soontornniyomkij B, Soontornniyomkij V, Achim CL, Reuter C, Irwin MR, Eyler LT, Jeste DV (2017) Abnormalities in chemokine levels in schizophrenia and their clinical correlates. Schizophr Res 181:63-69. https://doi.org/10. 1016/j.schres.2016.09.019

Ishmael FT, Fang X, Galdiero MR, Atasoy U, Rigby WFC, Gorospe M, Cheadle C, Stellato C (2008) Role of the RNA-binding protein tristetraprolin in glucocorticoid-mediated gene regulation. J Immunol 180(12):8342-8353. https://doi.org/10.4049/jimmu nol.180.12.8342

Junttila MR, Li S-P, Westermarck J (2008) Phosphatase-mediated crosstalk between MAPK signaling pathways in the regulation of cell survival. FASEB J 22(4):954-965. https://doi.org/10. 1096/fj.06-7859rev

Kaminska B, Mota M, Pizzi M (2016) Signal transduction and epigenetic mechanisms in the control of microglia activation during neuroinflammation. Biochim Biophys Acta 1862(3):339-351. https://doi.org/10.1016/j.bbadis.2015.10.026

Khan IA, MacLean JA, Lee FS, Casciotti L, DeHaan E, Schwartzman JD, Luster AD (2000) IP-10 is critical for effector T cell trafficking and host survival in Toxoplasma gondii infection. Immunity 12(5):483-494. https://doi.org/10.1016/S1074-7613(00)80200-9

Kobayashi N, Kadono Y, Naito A, Matsumoto K, Yamamoto T, Tanaka S, Ji I (2001) Segregation of TRAF6-mediated signaling pathways clarifies its role in osteoclastogenesis. EMBO J 20(6):12711280. https://doi.org/10.1093/emboj/20.6.1271

Kotlyarov A, Neininger A, Schubert C, Eckert R, Birchmeier C, Volk H-D, Gaestel M (1999) MAPKAP kinase 2 is essential for LPSinduced TNF- $\alpha$ biosynthesis. Nat Cell Biol 1(2):94. https://doi. org/10.1038/10061

Kuan CY, Yang DD, Roy DRS, Davis RJ, Rakic P, Flavell RA (1999) The Jnk1 and Jnk2 protein kinases are required for regional specific apoptosis during early brain development. Neuron 22(4):667-676. https://doi.org/10.1016/s0896-6273(00)80727-8

Lahti A, Kankaanranta H, Moilanen E (2002) P38 mitogen-activated protein kinase inhibitor SB203580 has a bi-directional effect on iNOS expression and NO production. Eur J Pharmacol 454(23):115-123. https://doi.org/10.1016/S0014-2999(02)02490-1

Lahti A, Jalonen U, Kankaanranta H, Moilanen E (2003) c-Jun NH2terminal kinase inhibitor anthra $(1,9-\mathrm{cd})$ pyrazol-6 $(2 \mathrm{H})$-one reduces inducible nitric-oxide synthase expression by destabilizing mRNA in activated macrophages. Mol Pharmacol 64(2):308315. https://doi.org/10.1124/mol.64.2.308

Lahti A, Sareila O, Kankaanranta H, Moilanen E (2006) Inhibition of p38 mitogen-activated protein kinase enhances c-Jun N-terminal kinase activity: implication in inducible nitric oxide synthase expression. BMC Pharmacol 6(1):5. https://doi.org/10.1186/ 1471-2210-6-5

Lee J-W, Nam H, Yu S-W (2016) Systematic analysis of translocator protein $18 \mathrm{kDa}$ (TSPO) ligands on toll-like receptors-mediated pro-inflammatory responses in microglia and astrocytes. Exp Neurobiol 25(5):262-268. https://doi.org/10.5607/en.2016.25.5. 262

Lehmann SM, Krüger C, Park B, Derkow K, Rosenberger K, Baumgart J, Trimbuch T, Eom G, Hinz M, Kaul D (2012) An unconventional role for miRNA: let-7 activates toll-like receptor 7 and causes neurodegeneration. Nat Neurosci 15(6):827. https://doi. org/10.1038/nn.3113

Lobo-Silva D, Carriche GM, Castro AG, Roque S, Saraiva M (2017) Interferon- $\beta$ regulates the production of IL- 10 by toll-like receptor-activated microglia. Glia 65(9):1439-1451. https://doi.org/ 10.1002/glia.23172 
Loniewski KJ, Patial S, Parameswaran N (2007) Sensitivity of TLR4and-7-induced NFKB1 p105-TPL2-ERK pathway to TNF-receptor-associated-factor- 6 revealed by RNAi in mouse macrophages. Mol Immunol 44(15):3715-3723. https://doi.org/10.1016/j. molimm.2007.04.002

Melief J, Sneeboer MAM, Litjens M, Ormel PR, Palmen S, Huitinga I, Kahn RS, Hol EM, de Witte LD (2016) Characterizing primary human microglia: a comparative study with myeloid subsets and culture models. Glia 64(11):1857-1868. https://doi.org/10.1002/ glia. 23023

Michaelis M, Kleinschmidt MC, Doerr HW, Cinatl J Jr (2007) Minocycline inhibits West Nile virus replication and apoptosis in human neuronal cells. J Antimicrob Chemother 60(5):981-986. https:// doi.org/10.1093/jac/dkm307

Miller BJ, Buckley P, Seabolt W, Mellor A, Kirkpatrick B (2011) Metaanalysis of cytokine alterations in schizophrenia: clinical status and antipsychotic effects. Biol Psychiatry 70(7):663-671. https:// doi.org/10.1016/j.biopsych.2011.04.013

Monguió-Tortajada M, Franquesa M, Sarrias M-R, Borràs FE (2018) Low doses of LPS exacerbate the inflammatory response and trigger death on TLR3-primed human monocytes. Cell Death Dis 9(5):499. https://doi.org/10.1038/s41419-018-0520-2

Morris BJ, Pratt JA (2014) Novel treatment strategies for schizophrenia from improved understanding of genetic risk. Clin Genet 86(5):401-411. https://doi.org/10.1111/cge.12485

Mufson EJ, He B, Nadeem M, Perez SE, Counts SE, Leurgans S, Fritz J, Lah J, Ginsberg SD, Wuu J (2012) Hippocampal proNGF signaling pathways and $\beta$-amyloid levels in mild cognitive impairment and Alzheimer disease. J Neuropathol Exp Neurol 71(11):1018-1029. https://doi.org/10.1097/NEN.0b013 e318272caab

Nagamoto-Combs K, Kulas J, Combs CK (2014) A novel cell line from spontaneously immortalized murine microglia. J Neurosci Methods 233:187-198. https://doi.org/10.1016/j.jneum eth.2014.05.021

Nakamichi K, Saiki M, Sawada M, Takayama-Ito M, Yamamuro Y, Morimoto K, Kurane I (2005) Rabies virus-induced activation of mitogen-activated protein kinase and NF- $\mathrm{\kappa B}$ signaling pathways regulates expression of $\mathrm{CXC}$ and $\mathrm{CC}$ chemokine ligands in microglia. J Virol 79(18):11801-11812. https://doi.org/10. 1128/JVI.79.18.11801-11812.2005

Olson JK, Miller SD (2004) Microglia initiate central nervous system innate and adaptive immune responses through multiple TLRs. J Immunol 173(6):3916-3924. https://doi.org/10.4049/jimmu nol.173.6.3916

Openshaw RL, Kwon J, McColl A, Penninger JM, Cavanagh J, Pratt JA, Morris BJ (2019) JNK signalling mediates aspects of maternal immune activation: importance of maternal genotype in relation to schizophrenia risk. J Neuroinflamm 16(1):18. https://doi.org/10.1186/s12974-019-1408-5

Pagès G, Guérin S, Grall D, Bonino F, Smith A, Anjuere F, Auberger P, Pouysségur J (1999) Defective thymocyte maturation in p44 MAP kinase (Erk 1) knockout mice. Science 286(5443):1374. https://doi.org/10.1126/science.286.5443.1374

Pauls E, Nanda SK, Smith H, Toth R, Arthur JSC, Cohen P (2013) Two phases of inflammatory mediator production defined by the study of IRAK2 and IRAK1 knock-in mice. J Immunol 191(5):2717-2730. https://doi.org/10.4049/jimmunol.1203268

Peltier DC, Simms A, Farmer JR, Miller DJ (2010) Human neuronal cells possess functional cytoplasmic and TLR-mediated innate immune pathways influenced by phosphatidylinositol-3 kinase signaling. J Immunol 184(12):7010-7021. https://doi.org/10. 4049/jimmunol.0904133

Prabhala P, Bunge K, Rahman MM, Ge Q, Clark AR, Ammit AJ (2015) Temporal regulation of cytokine mRNA expression by tristetraprolin: dynamic control by p38 MAPK and MKP-1.
Am J Physiol Lung Cell Mol Physiol 308(9):L973-L980. https://doi.org/10.1152/ajplung.00219.2014

Pyo H, Jou I, Jung S, Hong S, Joe E-h (1998) Mitogen-activated protein kinases activated by lipopolysaccharide and $\beta$-amyloid in cultured rat microglia. NeuroReport 9(5):871-874

Reimer T, Brcic M, Schweizer M, Jungi TW (2008) poly(I:C) and LPS induce distinct IRF3 and NF- $\mathrm{KB}$ signaling during type-I IFN and TNF responses in human macrophages. J Leukoc Biol 83(5):1249-1257. https://doi.org/10.1189/jlb.0607412

Remels L, Fransen L, Huygen K, De Baetselier P (1990) Poly I: C activated macrophages are tumoricidal for TNF-alpha-resistant 3LL tumor cells. J Immunol 144(11):4477-4486

Ribes S, Adam N, Ebert S, Regen T, Bunkowski S, Hanisch U-K, Nau R (2010) The viral TLR3 agonist poly (I: C) stimulates phagocytosis and intracellular killing of Escherichia coli by microglial cells. Neurosci Lett 482(1):17-20. https://doi.org/ 10.1016/j.neulet.2010.06.078

Righi M, Mori L, Libero GD, Sironi M, Biondi A, Mantovani A, Donini SD, Ricciardi-Castagnoli P (1989) Monokine production by microglial cell clones. Eur J Immunol 19(8):1443-1448. https://doi.org/10.1002/eji.1830190815

Ronkina N, Shushakova N, Tiedje C, Yakovleva T, Tollenaere MAX, Scott A, Batth TS, Olsen JV, Helmke A, Bekker-Jensen SH, Clark AR, Kotlyarov A, Gaestel M (2019) The role of TTP phosphorylation in the regulation of inflammatory cytokine production by MK2/3. J Immunol 203(8):2291-2300. https://doi.org/ 10.4049/jimmunol.1801221

Rutault K, Hazzalin CA, Mahadevan LC (2001) Combinations of ERK and p38 MAPK inhibitors ablate tumor necrosis factor- $\alpha$ (TNF$\alpha)$ mRNA induction evidence for selective destabilization of TNF- $\alpha$ transcripts. J Biol Chem 276(9):6666-6674. https://doi. org/10.1074/jbc.M005486200

Sánchez-Tilló E, Comalada M, Xaus J, Farrera C, Valledor AF, Caelles C, Lloberas J, Celada A (2007) JNK1 Is required for the induction of Mkp1 expression in macrophages during proliferation and lipopolysaccharide-dependent activation. J Biol Chem 282(17):12566-12573. https://doi.org/10.1074/jbc.M609662200

Scheltens P, Prins N, Lammertsma A, Yaqub M, Gouw A, Wink AM, Chu HM, van Berckel BNM, Alam J (2018) An exploratory clinical study of p38 $\alpha$ kinase inhibition in Alzheimer's disease. Ann Clin Transl Neurol 5(4):464-473. https://doi.org/10.1002/acn3. 549

Scherle PA, Jones EA, Favata MF, Daulerio AJ, Covington MB, Nurnberg SA, Magolda RL, Trzaskos JM (1998) Inhibition of MAP kinase kinase prevents cytokine and prostaglandin E2 production in lipopolysaccharide-stimulated monocytes. J Immunol 161(10):5681-5686

Schichl YM, Resch U, Hofer-Warbinek R, de Martin R (2009) Tristetraprolin impairs NF- $\kappa \mathrm{B} / \mathrm{p} 65$ nuclear translocation. J Biol Chem 284(43):29571-29581. https://doi.org/10.1074/jbc.M109. 031237

Shah S, Mostafa MM, McWhae A, Traves SL, Newton R (2016) Negative feed-forward control of tumor necrosis factor (TNF) by tristetraprolin (ZFP36) is limited by the mitogen-activated protein kinase phosphatase, dual-specificity phosphatase 1 (DUSP1) implications for regulation by glucocorticoids. J Biol Chem 291(1):110-125. https://doi.org/10.1074/jbc.M115.697599

Stansley B, Post J, Hensley K (2012) A comparative review of cell culture systems for the study of microglial biology in Alzheimer's disease. J Neuroinflamm 9(1):115. https://doi.org/10.1186/ 1742-2094-9-115

Swantek JL, Cobb MH, Geppert TD (1997) Jun N-terminal kinase/ stress-activated protein kinase (JNK/SAPK) is required for lipopolysaccharide stimulation of tumor necrosis factor alpha (TNF-alpha) translation: glucocorticoids inhibit TNF-alpha 
translation by blocking JNK/SAPK. Mol Cell Biol 17(11):62746282. https://doi.org/10.1128/MCB.17.11.6274

Swardfager W, Lanctôt K, Rothenburg L, Wong A, Cappell J, Herrmann N (2010) A meta-analysis of cytokines in Alzheimer's disease. Biol Psychiat 68(10):930-941. https://doi.org/10.1016/j. biopsych.2010.06.012

Swatton JE, Sellers LA, Faull RLM, Holland A, Iritani S, Bahn S (2004) Increased MAP kinase activity in Alzheimer's and down syndrome but not in schizophrenia human brain. Eur J Neurosci 19(10):2711-2719. https://doi.org/10.1111/j.1460-9568.2004. 03365.X

Takahashi Y, Yu Z, Sakai M, Tomita H (2016) Linking activation of microglia and peripheral monocytic cells to the pathophysiology of psychiatric disorders. Front Cell Neurosci 10:144. https://doi. org/10.3389/fncel.2016.00144

Tessaro FHG, Ayala TS, Nolasco EL, Bella LM, Martins JO (2017) Insulin influences LPS-Induced TNF- $\alpha$ and IL-6 release through distinct pathways in mouse macrophages from different compartments. Cell Physiol Biochem 42(5):2093-2104. https://doi.org/ 10.1159/000479904

Tiedje C, Holtmann H, Gaestel M (2014) The role of mammalian MAPK signaling in regulation of cytokine mRNA stability and translation. J Interferon Cytokine Res 34(4):220-232. https://doi. org/10.1089/jir.2013.0146

Town T, Jeng D, Alexopoulou L, Tan J, Flavell RA (2006) Microglia recognize double-stranded RNA via TLR3. J Immunol 176(6):3804-3812. https://doi.org/10.4049/jimmunol.176.6.3804

Tran EH, Azuma Y-T, Chen M, Weston C, Davis RJ, Flavell RA (2006) Inactivation of JNK1 enhances innate IL-10 production and dampens autoimmune inflammation in the brain. Proc Natl Acad Sci USA 103(36):13451-13456. https://doi.org/10.1073/ pnas.0601155103

Trudler D, Farfara D, Frenkel D (2010) Toll-like receptors expression and signaling in glia cells in neuro-amyloidogenic diseases: towards future therapeutic application. Mediat Inflamm. https:// doi.org/10.1155/2010/497987

Tu Y, Wu X, Yu F, Dang J, Wang J, Wei Y, Cai Z, Zhou Z, Liao W, Li L, Zhang Y (2019) Tristetraprolin specifically regulates the expression and alternative splicing of immune response genes in HeLa cells. BMC Immunol 20(1):13. https://doi.org/10.1186/ s12865-019-0292-1

Vogel C, Marcotte EM (2012) Insights into the regulation of protein abundance from proteomic and transcriptomic analyses. Nat Rev Genet 13(4):227. https://doi.org/10.1038/nrg3185

Wan J, Sun L, Mendoza JW, Chui YL, Huang DP, Chen ZJ, Suzuki N, Suzuki S, Yeh W-C, Akira S (2004) Elucidation of the c-Jun $\mathrm{N}$-terminal kinase pathway mediated by Epstein-Barr virusencoded latent membrane protein 1. Mol Cell Biol 24(1):192199. https://doi.org/10.1128/MCB.24.1.192-199.2004

Wang M-J, Jeng K-CG, Kuo J-S, Chen H-L, Huang H-Y, Chen W-F, Lin S-Z (2004) c-Jun N-terminal kinase and to a lesser extent, p38 mitogen-activated protein kinase regulate inducible nitric oxide synthase expression in hyaluronan fragments-stimulated BV-2 microglia. J Neuroimmunol 146(1-2):50-62. https://doi. org/10.1016/j.jneuroim.2003.10.034

Wang M-J, Huang H-Y, Chen W-F, Chang H-F, Kuo J-S (2010) Glycogen synthase kinase- $3 \beta$ inactivation inhibits tumor necrosis factor- $\alpha$ production in microglia by modulating nuclear factor $\kappa B$ and MLK3/JNK signaling cascades. J Neuroinflamm 7(1):99. https://doi.org/10.1186/1742-2094-7-99
Watters JJ, Sommer JA, Pfeiffer ZA, Prabhu U, Guerra AN, Bertics PJ (2002) A differential role for the mitogen-activated protein kinases in lipopolysaccharide signaling the MEK/ERK pathway is not essential for nitric oxide and interleukin $1 \beta$ production. J Biol Chem 277(11):9077-9087. https://doi.org/10.1074/jbc. M104385200

Wen J, Ribeiro R, Zhang Y (2011) Specific PKC isoforms regulate LPS-stimulated iNOS induction in murine microglial cells. J Neuroinflamm 8(1):38. https://doi.org/10.1186/1742-2094-8-38

Winchester CL, Ohzeki H, Vouyiouklis DA, Thompson R, Penninger JM, Yamagami K, Norrie JD, Hunter R, Pratt JA, Morris BJ (2012) Converging evidence that sequence variations in the novel candidate gene MAP2K7 (MKK7) are functionally associated with schizophrenia. Hum Mol Genet 21(22):4910-4921. https:// doi.org/10.1093/hmg/dds331

Wittenberg GM, Stylianou A, Zhang Y, Sun Y, Gupta A, Jagannatha PS, Wang D, Hsu B, Curran ME, Khan S (2019) Effects of immunomodulatory drugs on depressive symptoms: A megaanalysis of randomized, placebo-controlled clinical trials in inflammatory disorders. Mol Psychiatry. https://doi.org/10.1038/ s41380-019-0471-8

Yarza R, Vela S, Solas M, Ramirez MJ (2016) c-Jun N-terminal kinase (JNK) signaling as a therapeutic target for Alzheimer's disease. Front Pharmacol 6:321. https://doi.org/10.3389/fphar.2015. 00321

Yeh FL, Hansen DV, Sheng M (2017) TREM2, microglia, and neurodegenerative diseases. Trends Mol Med 23(6):512-533. https:// doi.org/10.1016/j.molmed.2017.03.008

Yu LE, Lai CL, Lee CT, Wang JY (2017) Highly electronegative lowdensity lipoprotein L5 evokes microglial activation and creates a neuroinflammatory stress via toll-like receptor 4 signaling. J Neurochem 142(2):231-245. https://doi.org/10.1111/jnc.14053

Zhang XY, Zhou DF, Zhang PY, Wu GY, Cao LY, Shen YC (2002) Elevated interleukin-2, interleukin- 6 and interleukin- 8 serum levels in neuroleptic-free schizophrenia: association with psychopathology. Schizophr Res 57(2):247-258. https://doi.org/10. 1016/S0920-9964(01)00296-1

Zhang T, Inesta-Vaquera F, Niepel M, Zhang J, Ficarro SB, Machleidt T, Xie T, Marto JA, Kim N, Sim T (2012) Discovery of potent and selective covalent inhibitors of JNK. Chem Biol 19(1):140 154. https://doi.org/10.1016/j.chembiol.2011.11.010

Zhao X, Guo Y, Jiang C, Chang Q, Zhang S, Luo T, Zhang B, Jia X, Hung M-C, Dong C, Lin X (2017) JNK1 negatively controls antifungal innate immunity by suppressing $\mathrm{CD} 23$ expression. Nat Med 23(3):337-346. https://doi.org/10.1038/nm.4260

Zhu W, Downey JS, Gu J, Di Padova F, Gram H, Han J (2000) Regulation of TNF expression by multiple mitogen-activated protein kinase pathways. J Immunol 164(12):6349-6358. https://doi.org/ 10.4049/jimmunol.164.12.6349

Zuiderwijk-Sick EA, Van der Putten C, Bsibsi M, Deuzing IP, De Boer W, Persoon-Deen C, Kondova I, Boven LA, Van Noort JM, t Hart BA (2007) Differentiation of primary adult microglia alters their response to TLR8-mediated activation but not their capacity as APC. Glia 55(15):1589-1600. https://doi.org/10.1002/glia.20572

Publisher's Note Springer Nature remains neutral with regard to jurisdictional claims in published maps and institutional affiliations. 